Future Machines: Assembling Transformation through Afrofuturist Imaginaries

\author{
James Perla \\ McLean, Virginia
}

BA in English Literature, The University of Virginia, 2015

A Thesis presented to the Graduate Faculty of the University of Virginia in Candidacy for the Degree of

Masters of Arts

\title{
Department of English
}

University of Virginia

May 2016 


\section{Table of Contents}

1. Rebooting Race: An Introduction to the Afrofuturist World of Signification

2. "It's After the End of the World": Assembling Identity through Future Archives

4. Conclusion: Multidimensional Machines to the Future and Back

5. Appendix 


\section{CHAPTER 1:}

\section{Rebooting Race: An Introduction to the Afrofuturist World of Signification}

In pop-icon Janelle Monáe's futuristic world, race is a technology and androids

dream of falling in love. Janelle Monáe's seven-part concept album tells the story of the android Cindi Mayweather, who falls in love with a human and must go into exile to avoid punishment for her transgressive act. Escaping into the Wondaground, a zone reminiscent of the Underground Railroad, Mayweather comes to represent a revolutionary figure that preaches to other androids the liberating power of self-love, dance, and cyber-soul to free "the citizens of Metropolis from the Great Divide" (BadBoy Records, 2010). ${ }^{1}$

While she draws on Fritz Lange's Metropolis, Monáe reframes the science fiction classic to discuss structural inequality built into the foundations of the U.S. In Lange's 1927 film, Maria prophesizes that a mediator will come to Metropolis in order to unite the working class and wealthy elite. Monáe's alter ego inhabits a re-imagining of Lange's world, such that her android becomes the prophetic female-savior capable of bridging the Great Divide both in her fictional world and the real world it allegorizes. Monáe fuels this reading by amplifying the power for her music to be a vehicle for transformation. During her performances, she distributes a list of "10 Droid Commandments," one of which is that "by the show's end you must transform.", In the video "Many Moons," her android

\footnotetext{
1 The liner notes of Monáe's first official album The ArchAndroid explain the Great Divide as “a secret society, which has been using time travel to suppress freedom and love through the ages" (BadBoy Records, 2010).

${ }^{2}$ Other notable commandments include: 6) Abandon your expectations about art, race, gender, culture and gravity. 7) Before the show, feel free to walk about the premise impersonating one of the many inspirations of the ArchAndroid Emotion Picture: (choose one) Salvador Dalí, Walt Disney, Outkast, Stevie Wonder, Octavia Butler, David Bowie, Andy Warhol, or John Williams.
} 
alter ego sacrifices herself to show other androids the potential in attempting to hack the technologies that confine them.

During a futuristic fashion show and an android auction reminiscent of the slave blocks, Cindi Mayweather transcends the limits of mechanical, preprogrammed performance. At the beginning of the video, she turns on her blackness, activating a uniform for performance that transforms her appearance from an automaton devoid of melanin to her seemingly "normal" black embodiment (Figure 1-3). In less than three seconds, Monáe represents what has taken scholars decades to explain: race is a technology. Specifically, race is a sociolinguistic and cultural formation, a collective hallucination created, policed, and manipulated by discourse, representations, and essentialized narratives about black and white bodies. In the video, Monáe demonstrates that the technologically and culturally constructed non-human android can love and achieve an otherworldly state of transcendence. Mayweather samples dance moves from Michael Jackson and James Brown and lays down her own funky moves to transport herself into another plane of existence that transcends her mechanical embodiment. Ultimately, the performance causes her to shut down. Mayweather's sacrificial act, while consistent with the historiography of how slaves reclaimed agency, ${ }^{3}$ shows that the technologies written into the source code of one's embodiment, can be hacked, rewritten, and transformed into new scripts for liberation. That is, if one has the proper vehicle. Monáe transports her listeners via cyber-soul and the immersive EmotionPictures, as she calls her songs, within each concept album. However, Monáe inherits and continues a long project of funky, future-oriented demigods with their own vehicles for

\footnotetext{
3 See Paul Gilroy The Black Atlantic: Modernity and Double Consciousness. Cambridge, Mass.: Harvard University Press, 1993
} 
transformation. Her work fits within an interstellar, multidimensional, and multimedia intellectual tradition called Afrofuturism, which uses future worlds to dissect the technologies that have historically represented, policed, and violated bodies of color in order to assemble new vessels to navigate time and space.

As Monáe's work suggests, future-imaginaries can radically reframe conceptions of race, time, and belonging within conventional modes of representation. By rupturing the essentialism of her embodiment as a black female performer and exploding it into a future space in which she exists simultaneously in multiple dimensions, spaces, and times, Monáe hacks the representational apparatus to create an allegory for transcendence that has material implications in the present tense. In a number of her songs and live performances, Monáe addresses listeners and encourages them to practice the same creative authorship that enabled her own transformation. ${ }^{4}$ More importantly, Monáe not only comforts listeners who feel like outsiders or aliens, but also shows the potency in inhabiting spaces of alterity. She exemplifies Dona Haraway's notion that "one is too few and two is only one possibility" because she demonstrates the transformative potential and sheer enjoyment of unsettling the binaries between black/white, female/male, homo/heterosexual, future/present (Haraway, 180). In a way, her Wondaland world is an Underground Railroad that forges new ways of being, new ways of navigating, new ways of seeing oneself in relation to the world; it hides in plain sight as pop music, but assembles alternative future-oriented ontologies that have the potential to transform listeners. In the two other works I explore in this project, the vessels for transformation

\footnotetext{
4 Before performing the song "Cold War" at the Nobel Peace Prize ceremony in 2011, Monáe said: "there was once a time when I didn't feel empowered as a young African American women. So I wrote this song, so that you no matter what your color is, all women and young girls can find their power."

(https://www.youtube.com/watch?v=4f990e8sSz4)
} 
build an aesthetic and ontological strategy in a virtual reality representation of the Internet and a near future dystopic landscape. In The Last Angel of History, a data-thief from 200 years in the future guides viewers through a virtual reality archive of black speculative culture to teach viewers how to assemble their own identities from fragments of official and unofficial history. In Parable of the Sower, a prophetic young woman builds a community through a set of religious tenets that draw from Baptist Christianity, Tibetan Buddhism, and Western scientific knowledge like the second law of thermodynamics. Her future-oriented belief system neither comforts nor proselytizes, but rather encourages action in the present moment to shape the invisible elements in the world in order to change one's circumstances and help others along the way.

Afrofuturism began as a contested term when the cultural critic Mark Dery attempted to categorize the African American world of signification as he saw it. In his influential 1993 essay "Black to the Future," Mark Dery coined “Afro-Futurism” to categorize a body of work that appropriates elements of science fiction to address the concerns of African Americans in twentieth century technoculture. Dery began his essay with the question "why do so few African American writers write science fiction?" (Dery, 179) He argued that the science fiction genre seems so well suited to address the experiences of alienation, invisibility, and exploitation enacted by technology upon African Americans historically and into the present. Greg Tate, a prominent Afrofuturist critic quickly pointed out the misnomer in Dery’s proposition, citing Ralph Ellison among others, to show African American literature has always been very much invested in the fantastic; it just might not look like conventional science fiction stories. Since 
Dery's essay, scholars have published an enormous a number of anthologies ${ }^{5}$ and articles to define and redefine Afrofuturism ${ }^{6}$, its tenets, its tools, and its delimitations. ${ }^{7}$ In this project, I take Afrofuturism as a set of aesthetic practices or tools for transformation that assemble into a machine ${ }^{8}$ — broadly defined as a transportation device, aesthetic interface, or an ontological system. ${ }^{9}$ More simply, one could describe this as a poetics with all of the etymological currency of poiesis as making or becoming. I argue that through a set of aesthetic conventions — such as bricolage, world building, and future-oriented ontologies-Afrofuturist practitioners in literature, film, and music deconstruct and reconstruct their place in the world to become something other than a racialized Other. With regard to its historical influences, Afrofuturism negotiated the traditions of the Black Arts Movement, Black Power, Pan-Africanism, Négritude, and the Civil Rights Movement. In a conversation Carl Freedman, the prominent science fiction writer Samuel R. Delany comments on the legacy of the Civil Rights Movement in the context of his

\footnotetext{
${ }^{5}$ See Dark Matter (I and II) (2000), Whispers from the Cotton Tree Root: Caribbean Fabulist Fiction (2000), Mojo: Conjure Stories (2003), and So Long Been Dreaming: Postcolonial Science Fiction \& Fantasy (2004). AfroSF: Science fiction by African Writers (2012), Mothership Tales from Afrofuturism and Beyond (2013), Afrofuturism: The World of Black Sci-Fi and Fantasy Culture (2013) Octavia's Brood: Science Fiction Stories from Social Justice Movements (2015)

6 See "Afrofuturism 2.0 and the Black Speculative Art Movement: Notes on a Manifesto" for a catalog of terms contained within Afrofuturism, among them are "Black Quantum Futurism, African Futurism, Afrofuturismo...Astro-Blackness, Afro-Surrealism, Ethno-Gothic..."

${ }^{7}$ While Dery defined the term as a practice of signification, Alondra Nelson underscores that Afrofuturism is neither a movement, nor a mantra, but a critical perspective (Nelson, 2000). Though, she would later describe Afrofuturism as "a feminist movement" in an interview with Ytasha Womack (Womack, 2013). D.J. Spooky and Kodwo Eshun imagine it in a similarly amorphous way as an "osmotic strategy" and "a field," respectively (Van Veen, 2013; Eshun, 2003).

${ }^{8}$ Though I use the word "machine," it is largely independent of Gilles Deleuze and Feliz Guattari's writing on "desiring-production" in Anti-Oedipus: Capitalism and Schizophrenia. Minneapolis: University of Minnesota Press, 1983. See also: Benitez Rojo The Repeating Island: the Caribbean and the Postmodern Perspective. Durham: Duke University Press, 1992.

9 Etymologically machine has valences that fit with my usage: from Latin meaning "engine, military machine; device, trick"; Greek makhana "contrivance, machine, engine", a derivation from $\mu \tilde{\eta} \chi o \varsigma$ mekhos "means, expedient, remedy". Similarly, the word engine, used as a near synonym comes from the Latin ingenium "ingenuity, an invention". In addition to its contemporary connotations, the key linkages I wish to highlight here are "device, remedy, and invention."
} 
work. Delany emphasizes that what was once a movement attempting to change specific social institutions and policies through legislation expanded into a "social project, whose focus was the elimination of a set of stances, attitudes, and actions among people" (Barr, 219, emphasis in original). As such, the representational battles for imaginative terrain seemed a practical and urgent endeavor. While the cyberpunk science fiction in vogue at the time similarly used science fiction to discuss the notions of fragmentation and alienation within an exploitative technoculture, their future-imaginings whitewashed the fact that these realities were the "changing same" 10 for people of color. I do not intend to discount the merits of the cyberpunk movement, but rather show that "space is the place" for black cultural producers. In what follows, I argue that through Afrofuturism, African diasporic writers, filmmakers, and musicians master the technologies—scientific, sociolinguistic, and cultural— to take control of their destiny.

Two of the foremost concerns in Afrofuturism are space and time. In Afrofuturism: the World of Black Sci-Fi and Fantasy Culture, Ytasha Womack argues that black cultural producers have to create a space, literally and figuratively, in which to think freely so that they can control the terms of their own representation. Through these spaces, black cultural producers announce their presence in the world as multidimensional, agentive subjects unmoored from the normative order that confines them to be alien, invisible, and marginal. Though some future renderings may be reactionary or regressive, at times intentionally so, ${ }^{11}$ Womack characterizes Afrofuturist work as

\footnotetext{
10 See Amiri Baraka. The Leroi Jones/Amiri Baraka Reader. Ed. William J Harris. New York: Thunder's Mouth Press (1991) and Deborah E. McDowell "The Changing Same": Black Women's Literature, Criticism, and Theory. Bloomington, Ind.: Indiana University Press (1995)

${ }^{11}$ See George Schuyler, and Robert A Hill. Black Empire. Boston: Northeastern University Press, 1991.
} 
focused on recovery, healing, and action to repair the psychological and historical traumas unfolding in the present moment.

The title of Alondra Nelson's essay “Afrofuturism: Past-Future Visions” underscores a key premise in Afrofuturism's chronology, or as Kodwo Eshun calls it "chronopolitics." 12 Specifically, the way past-future visions_-imagining culturally and historically relevant elements of the African diaspora in future renderings - can reformulate the conceptions of African diasporic people's position in time. In the essay, Alondra Nelson takes issue with Mark Dery's essay, stressing that by defining membership based on race, Dery misses the practice of innovation inherent in the African diasporic practice of continually remaking and reinventing selfhood in environments of exploitation and violence. Nelson proposes to reformulate Afrofuturism in the context of black technology and innovation rather than through the essentialized taxonomy of race. Among others, ${ }^{13}$ she cites Kodwo Eshun's writing in More Brilliant than the Sun as an example of how Afrofuturism overlays science and cultural expression to reconceive notions of race.

Eshun argues that black music, even before hip-hop sampling, engaged in a scientific technique. In reinterpreting black music as always already scientific, Eshun attempts to unhinge essentialized notions of blackness vis-à-vis technology, cultural expression, and future imaginings. ${ }^{14}$ In other words, by brining the "futurism" to bear on

\footnotetext{
12 See "Further Considerations on Afrofuturism" CR: The New Centennial Review 3.2 (Summer 2003)

${ }^{13}$ These include: Fatimah Tuggar's photographs of cyborg realism in Nigeria, Tricia Rose's Black Noise: Rap Music and Black Culture in Contemporary America (1994), and Samuel R. Delany's oft-cited quote: "We need images of tomorrow; and our people [black people] need them more than most" (Nelson, 37).

${ }^{14}$ In his larger critical contributions of Afrofuturist theory, Kodwo Eshun discusses this technique with regard to time. He writes how Afrofuturism enables practitioners to alter the temporal logics that condemn black subjects to prehistory, invisibility, and alienation. He makes the claim that science fiction does not concern itself as much with the future, but rather the way future imaginaries engineer feedback into the
} 
the "Afro," Nelson writes, "race disappears into technology" (Nelson, 2000). More specifically, race only "disappears" when one learns that race is a culturally constructed, culturally enforced trick of sociolinguistic technology. In reinterpreting race as a technology and re-injecting the past into the future, Afrofuturist practitioners can hack, master and reverse engineer its signification to their own ends in the present. Eshun and Nelson's writings unearth Afrofuturism's central tension: reconciling the "Afro" and the "futurism," which in turn creates further tensions between cultural specificity and posthumanism, dystopia and utopia, and between a culturally essentialist generic codification and a more hybridized, fluid conceptualization.

My project will investigate these central tensions within Afrofuturist theory to argue that the process of deconstructing embodiment and time - enabled by the aesthetic conventions of bricolage, temporal realignment, and prophetic narratives - make the categories themselves mutable, contingent, and subject to transformation; Afrofuturist works master the technologies of race, history, and time in order to repurpose (read: hack) them for culturally specific works of art. In these hacked worlds, future-oriented ontologies assemble machines for individual and communal becoming. Two theorists will inform my analysis: Houston A. Baker's notion of the "black (w)hole" and Achille Mbembe's theorization on self-writing. ${ }^{15}$ Both authors underscore the generative potential for black expressive culture to transform subjectivities through otherworldly experiences, pointing to religion and music as ritualized zones that deliver moments of timelessness and spacelessness and cast spells upon the present (Baker, 152; Mbembe

present. Eshun's term "chronopolitics" refers to the techniques by which Afrofuturists engineer this counterhegemonic feedback loop (Eshun, 292).

${ }^{15}$ See Blues, Ideology, and Afro-American Literature: a Vernacular Theory. (Chicago: University of Chicago Press, 1987) and "African Modes of Self-Writing" Public Culture 14.1 (2002). 
262). My argument will trace how Afrofuturist artists create transformation machines, new worlds, texts, and scripts (based in bricolage, fragments of historical memory, and future-oriented imaginaries) that attend to the historical experiences of people of color only insofar as they provide the keys for the reformulation of categories that have historically bound them.

The works that I investigate contain prophetic figures attempting to excavate, narrate, and imagine alternatives to the codes of race, history, and religion. In Parable of the Sower, Octavia Butler writes the story of how a young black woman in a dystopic near future creates an alternative belief system composed of fragments of canonical religions. Through her new religion, based in practical action and the notion that God is Change, the protagonist not only avoids violence and neo-slavery, but also helps others to escape violence and exploitation. In The Last Angel of History, an essay film created by John Akomfrah and the Black Audio Film Collective, the data-thief, a time-traveller from 200 years in the future, navigates a representation of the Internet to assemble a vault of racial memory. The project of unlocking the keys to the future requires the data-thief and the viewer to learn the language of black speculative culture and develop a new way of seeing the world through a future-oriented ontology. 
Perla 11 


\section{CHAPTER 2:}

\section{"It's After the End of the World": Assembling Identity through Future}

\section{Archives}

In 1982, a group of seven black British multimedia artists founded an arts organization with the theories of Homi Bhabha and Stuart Hall filling their notebooks and minds. Throughout a prolific decade, the Black Audio Film Collective (BAFC) made "some of the most challenging and experimental documentaries in Britain" that unearth the realities, challenges, and traumas of the immigrant experience as a raced body (Ward, 2013). For example, they filmed Handsworth Songs during the 1985 riots in Birmingham - mixing newsreels, soundscapes, interviews, and archival photographs from the $1950 \mathrm{~s}$ - to capture the experience of the British diasporic community as a personal account rather than an authoritative, journalistic, or documentarian truth. Similarly, in Seven Songs for Malcolm X, the Black Audio Film Collective created a layered poetic homage to the life of Malcolm X with a multiplicity of voiceovers from his family, former aids, eyewitnesses, and scholars, as well as archival video and dramatic reenactments. John Akomfrah, the foremost filmmaker in the Collective, defines their style as bricolage, which etymologically suggests the notion of do-it-yourself, but also contains within it an assumption of an experimental assemblage using mass-produced junk, found objects, and the discarded detritus of technoculture. The term has a rich history in cultural studies and critical theory as well as music, visual arts, art history and architecture. Broadly speaking, from Claude Lévi-Strauss to Jacques Derrida to Gilles Deluze and Félix Guattari, bricolage refers to an experimental, often times schizophrenic, mode of cultural production that attempts to address the ruins of an artistic or cultural 
heritage through mythical thought and imagination. For example, the punk music culture imbued the safety pin with totemic qualities, appropriating it as an item of technoculture and consumption that symbolically pieced together the experience of fragmentation and despair. While Afrofuturism draws from some of the postmodern notions of fragmentation and silence, it avoids the renunciation of signification and unity for silence and irony. Rather, as I demonstrate in these chapters, Afrofuturism attempts to build new worlds from the always already fragmented and traumatic pieces of African diasporic existence. It draws from the structures of nationalism, religion, generic aesthetics, and discourses of race not to re-present them as ironic readymades, but instead to create a set of tools with which to hack their hierarchical logics. The machine produces a new source code, a parallel ontology or alternative ethics that negotiates and attempts to transcend the limitations of the social, national, and raced body. In this section, I discuss a Black Audio Film Collective's essay-film the Last Angel of History, which creates a future-archive of Afrofuturism for a yet undefined group of black creatives. In so doing, the BAFC creates an African diasporic filmic space — a virtual reality—that records the plurality of blackness, transcribes a lexicon for black creative expression, and attempts to unlock the keys to the future for the historically alien raced body. Far removed from The Last Angel of History's release in 1996, Akomfrah's work is ever relevant in the present moment because it demonstrates the need to construct spaces within the Internet that attend to the experiences of people of color without replicating the latent ideologies or structures of technological control.

The film uses collective mythologies, archival materials, and otherworldly sounds to create a virtual reality in which individuals can negotiate historical trauma and utilize 
mythmaking to forge connections to individuals across transatlantic space and time. In the film a time-traveller from 200 years in the future, referred to as the "data-thief," journeys to Earth in search of the code that holds the keys to the future; his only clue: "Mothership Connection." African diasporic history, music, and culture comprise the raw data of his search and the "Mothership Connection," the name of George Clinton's PFunk concept album, becomes the sonic, visual, and interpersonal linkages between Afrofuturists across time and space. The film itself represents an archive of the datathief's journey in that the viewer witnesses the data-thief's discovery, collation, and cataloging of the fragments of information or, as the narrator would say, the "technofossils" of the "archeological dig." The data-thief unearths raw data, which include interviews with Afrofuturist writers, musicians, and theorists. Based on the subject matter of each interview, the data-thief transports him/herself and the viewer to the locations in question such as Detroit, Ghana, Britain, and Jamaica. The interviews mix with the film's jarring aesthetics, musical pulse, seemingly haphazard cuts, and otherworldly spaces of oversaturated colors. Akomfrah deploys the aesthetics of Afrofuturism to construct a fictional space that archives black speculative culture in order to engineer a futureoriented ontology for the viewer to use in the present moment. This virtual reality space represents the digital world and, more specifically, the vault of the Internet's racial memory. In her book Afrofuturism: the World of Black Sci-Fi and Fantasy Culture, Ytasha Womack emphasizes the importance of space in Afrofuturist art: Whether it's outer space, the cosmos, virtual space, creative space, or physical space, there's this often-understated agreement that to think freely and creatively, 
particularly as a black person, one has to not just create a work of art, but literally or figuratively create the space to think it up in the first place (Womack, 147). By using outer space as an organizing principle, a number of cosmically inspired musicians began Afrofuturism's musical genealogy in jazz, funk, and reggae. These forefathers include: Sun Ra, the self-proclaimed alien from Saturn and jazz musician, George Clinton, the master behind the bands Parliament and Funkadelic, and Lee "Scratch" Perry, the creative genius who pioneered dub through the use of sampling technology in his Black Ark Studios. Each artist fixated on the concept of vehicles in their art. Sun Ra's "Arkestra" was the jazz ensemble or orchestra that played his otherworldly compositions. George Clinton's "P-Funk Mothership" was a literal and figurative vehicle, a hugely popular stage-prop that also delivered the funk. Lee "Scratch" Perry's Black Ark studio, set up in his back yard in Kingston, Jamaica became a mecca for reggae artists such as Bob Marley and the Wailers, the Congos, and Max Romeo, among others. In the context of Womack's assertion, these mythic machines provided the figurative space and the vehicle "to think freely and creatively" (Womack, 147). For Sun $\mathrm{Ra}$ and George Clinton, the mental space enabled the psychic mobility to create a mythology around their persona, to shape shift and transcend into epic and mythical proportions. Lee "Scratch" Perry created a physical space, the Black Ark Studios, where he recorded some of Jamaica's most innovative sounds. Whether as an album, a fully integrated persona, or a physical location the earliest practitioners of Afrofuturism overstated the importance of creating both a physical and mental space in their work through symbology of outer space. In the film, the data-thief and the viewer navigate the virtual archive of the Afrofuturism observing and writing the genealogies, sounds, and 
stories into existence. The journey renders a figurative space that allows African diasporic subjects to negotiate their collective lived experiences within and in spite of official systems of discourse and memory that inscribe history and individuals into their respective places within space, time, and culture. In this rendering, the data-thief assembles fragments from the historical archive to enact a process of subject formation that takes black speculative culture as a foundational principle. As such, the project is both literal and allegorical. His virtual excavation of the obfuscated memories and unofficial histories provides a script for action which allegories the black subject's project of assembling one's place in the world from fragments of history not contained within the official archive. Yet, Akomfrah presents this imaginative excavation as rooted in physical spaces and individuals within history, which include musicians, writers, astronauts, and cultural theorists in California, Detroit, Jamaica, Ghana, and Britain.

\section{"The first thing to do is consider time officially ended"}

As a medium, film has historically projected stereotypes onto the collective's optic nerve. ${ }^{16}$ As the brief sketch of the BAFC's opus suggests, there is an anthropological impetus in their work to document the experiences of people of color with methodological tools that reflect the richness, complexity, and thickness of the present moment. As numerous critics have shown, the film medium has historically reified, essentialized, and structured the normative way to view people of color. ${ }^{17}$ In this way, the Black Audio Film Collective's project, as they described it in an interview with

\footnotetext{
${ }^{16}$ Etymologically, "stereotype," French stéréotype (adj.) comes from the method of printing a solid plate (Gk. stereos).

${ }^{17}$ See Jesse A. Rhines Black Film, White Money. New Brunswick, N.J.: Rutgers University Press, 1996. Stuart Hall and Sut Jhally Representation \& the Media. Northampton, MA: Media Education Foundation, 1997. Bell Hooks “The Oppositional Gaze: Black Female Spectators,” Black Looks: Race and Representation. Boston: South End Press, 1992
} 
Paul Gilroy, is to (re/de)center the filmic gaze and in turn the black subject's view of his or her own position within the discursive world order. More broadly, Afrofuturism attempts this reformulation on a larger scale, both representationally (to put black people in future imaginaries), psychologically (to hack the discourses and psychological structures that produce alienation), and materially (to enact Afrofuturism's utopian projections in the "real" world). John Akomfrah and Edward George of the BAFC cite Bhaba's writing on hybridization and envision their audiences as a "diasporic constituency" that are just "as much a hybrid as [they] are" (Gilroy, 12). Though recent scholarship has taken issue with terms like hybridity and multiculturalism, Akomfrah summarizes the hybrid logic as an attempt to "forge identity which isn't rooted in an essentialist understanding of one's origins" (Gilroy, 13). Just as the "truth" in the BAFC's cultural productions pertaining to the Handsworth riots and Malcolm X is never authoritative, ethnographic, or mimetic, the imaginary audience always lies outside of the camera's frame, conjugated in a subjunctive tense, and positioned in an interstitial space of becoming real, yet perpetually mediated by the sociolinguistic formations of nationalism, culture, and race. In order to get beyond the representational, sociolinguistic, and cultural technologies of mediation, one must transcend time and space entirely.

Before turning to The Last Angel of History, the film Space is the Place provides an extreme example of attempting to transcend the space-time continuum and underscores the stakes of assembling a future-oriented ontology through creative representation. In the film, the mercurial jazz musician, scholar, and self-proclaimed alien from Saturn, Sun Ra transports a colony of black migrants to another planet in order to save them from the "alien/nation" of Planet Earth. Ra uses his otherworldly music to tune 
his future-Earth-exiles to a different multidimensional frequency. In the movie's prologue Ra explains:

The music is different here. The vibrations are different. Not like Planet Earth. Planet Earth sounds of guns, anger, frustration. There will be no one from Planet Earth we could talk to who would understand. We'll set up a colony for black people here. See what they can do on a planet all their own, without any white people there. They would drink in the beauty of this planet. It would affect their vibrations, for the better, of course. Another place in the universe, up in the different stars. That would be where the alter-destiny would come in. Equationwise - the first thing to do is to consider time as officially ended (Coney, 1:542:41)

Ra's assertion to "consider time officially ended" suggests an end times chronology that (de/re) centers conventional notions of time. Consistent with the phrase that echoes in the film, "it's after the end of the world, don't you know that yet," Ra's underscores the fact that the apocalypse has already happened for people of color in the form of slavery and the ongoing manifestations of Blaxploitation. ${ }^{18}$ In placing African diasporic present after the end of the world, the Afrofuturist space is timeless and placeless, thus outside of any utopian teleology rooted in "progress." Kodwo Eshun's theorization on chronopolitics explains how this approach to time, space, and history uses futurity to reverse engineer an ontological position for the present moment. ${ }^{19}$ This process of hacking the present using future spaces imagines alternatives to racially codified and historically enforced notions of blackness. Ra terms this reformulation of the African diasporic subject's position in

\footnotetext{
${ }^{18}$ Ra's biographer John Szwed called the film "part documentary, part science fiction, part Blaxploitation and part revisionist biblical epic" (Szwed, 330).

${ }^{19}$ See "Further Considerations on Afrofuturism" CR: The New Centennial Review 3.2 (Summer 2003)
} 
time and space as an "alter-destiny" that projects the destiny of people of color beyond Earth to an infinity in which the codes that bind blackness follow a different script. Michel Foucault's notion of "heterotopia" offers a fitting framework for what Ra's "alterdestiny" envisions. Foucault argues that in contrast to a utopia, which is a fundamentally unreal space, heterotopias are real-unreal spaces. In the same way, a mirror image is a virtual rendering, but also a type of shadow that "exists" in the world only to make one's embodiment visible to oneself, so too do "heterotopias" enact, frame, and construct a utopia (Foucault, 4). Like Ra's alter-destiny, these parallel worlds impinge on one's present time and space to provide interstitial spaces of becoming, quasi-places or vessels through which to enact or arrive at a utopia. As such, these "placeless places" are both hyper-specific and inherently plural; they provide a microcosm composed of layered sites and temporalities. ${ }^{20}$ While Sun Ra broadcasts his alter-destiny through music, transporting listeners to other worlds via the frequencies from his Arkestra, Akomfrah uses bricolage to create a heterotopia in the film medium. The data-thief navigates the virtual reality and learns how a heterotopic future-archive can provide a vehicle for becoming.

John Akomfrah and the BAFC reimagine central themes in Ra's Space is the Place for an Internet-saturated world. Sun Ra's phrase "it's after the end of the world, don't you know that yet" echoes as a mantra in Akomfrah's film. In the world of The Last Angel of History each body contains its own archive of collective memory that links to

\footnotetext{
20 "The heterotopia is capable of juxtaposing in a single real place several spaces, several sites that are in themselves incompatible. Thus it is that the theater brings onto the rectangle of the stage, one after the other, a whole series of places that are foreign to one another; thus it is that the cinema is a very odd rectangular room, at the end of which, on a two-dimensional screen, one sees the projection of a threedimensional space" (Foucault, 6)
} 
other people of color across transatlantic space and time. In 2008, the South African publication Chimurenga published the BAFC's "guiding script" for the film, which explains the logic of time travel and teleportation in the film: "on this future-Internet the space-time continuum has been realigned so that each image holds multiple traces of its past, held forever in a state of suspension in cyberspace" (Akomfrah, 1993). In many ways, Akomfrah is attempting to represents the digital hyperlink in the film medium. For example, when the data-thief finds George Clinton's album "Mothership Connection," the film immediately transports to George Clinton himself explaining the album. It then "links" again to the first African American in space, who listened to P-Funk in college. In this way, the director outside of the film's frame curates these connections between black futurologists to create an archive of racial memory through the film itself. The nongendered, time-traveling trickster figure exists within the film and narrativizes the action of thieving the authoritative archive in order to create something new. ${ }^{21}$ The Last Angel of History shows the inherency of world building and hacking in Afrofuturist works in that the physics of Akomfrah's universe only function by adjusting the given chronology, stealing fragments from the official History of people of color, and creatively reassembling the units of source code in order to create generative, culturally specific spaces where black cultural practitioners can express themselves without the confinements of essentialized notions of race, gender, or history.

In the film the data-thief"s mission is to "unlock the keys to his future;" however in the script, s/he is sent to steal ideas "for a high-brow cerebral mind-park called Babel-

${ }^{21}$ A detail that emerges in the script, but remains unclear in the film is the fact that the data-thief is nongendered. In the script, Akomfrah and George write: "To aid us on this journey we have chosen a mythical figure from the African Diaspora - s/he's a trickster/hustler/Stagolee in a new incarnation - the data thief" (Akomfrah 1993). 
17," which alludes to Samuel R. Delany's 1966 novel, Babel-17. ${ }^{22}$ What the allusion to Delany suggests and The Last Angel of History attempts to relay is the role of language as a technology; by extension, the language of race becomes an ideological technology to be weaponized against the marginalized, deployed as prosthetic enhancements for normative, and serve as mind control devices more broadly. As Hortense Spillers succinctly puts it in her essay "Mama's Baby, Papa's Maybe," "sticks and stones might break our bones, but words will most certainly kill us" (Spillers, 68 emphasis in original). In The Last Angel of History, the data-thief discovers the language, mythology, and collective genealogy of Afrofuturism, which reframes the description of people of color as agentive subjects that have the power to control their own technologies, representational, linguistic, and mechanical. The Last Angel of History theorizes ways to alter the perceptions of blackness and possibilities for black people through creatively representing history and the future. Afrofuturism builds worlds in the (near, far, distant) future order to interrogate hierarchical formations outside a linear time scale to imagine an "alter-destiny" for people of color that does not contain physical and mental violence of trauma, objectification, invisibility, and alienation.

\section{Afrofuturist ancestor worship}

The data-thief learns that in order to have access to what he calls the "secret technology" of the African diaspora, one must understand the collective consciousness and historical context from which Africans of the diaspora emerged; in short, one must understand genealogy. To quote the film, "blues begat jazz, which begat soul, which begat, hip hop, which begat R\&B," much in the same way that the forefathers of

22 Delany's novel draws on the then in vogue Sapir-Whorf theory of linguistic relativity and imagines a world in which language is a weapon, a prosthetic enhancement, and a mind control device all in one. 
Afrofuturism—Sun Ra, George Clinton, and Lee Scratch Perry—begat the main practitioners in the Detroit techno scene—Derrick May, Juan Atkins, and DJ Spooky. However, DJ Spooky makes clear that the network of influences operates as a non-linear, multidirectional exchange. He references how the history of African slaves in the New World communicating across space through drums influenced his approach to communicating through electronic samples between historical time and physical space. Greg Tate uses the notion of sampling technology to explain the way in which the Afrofuturist aesthetic flattens space and time as well as the effects of such a collapse: What sampling technology has allowed in the area of black musical production is digitized race memory. Sampling allows for a generation that didn't have access to musical education a way of collapsing all eras of black music onto a chip and to be able to freely reference and cross-reference all those eras of sound and previous generations of creators, simultaneously (Last Angel of History, 35:09$35: 41)$

Tate's contribution highlights the simultaneity and immediacy of sampling the way it collapses time and space, rendering sampling as a type of sonic virtual reality that flattens time and extends across space. Similarly, in the film's virtual reality world, the data-thief attempts to catalog and encrypt the different eras and generations of creators within black speculative culture. Tate continues this discussion describing how "music belongs to the people, and sampling isn't a copycat act but a form of reanimation. Sampling in hip-hop is the digitized version of hip-hop DJing, an archival project and an artform unto itself. Hip-hop is ancestor worship" (Tate, 73). Implicit in Tate's discussion of sampling is the older tradition to which DJ Spooky alludes of ritual drum ceremonies offering a way to 
enter the spirit realm through ritual and embodied performance. In this way, DJ Spooky's notion of communicating across space and time as well as Tate's notion of "reanimation" necessarily entails transportation to other worlds and different dimensions through music as an aesthetic vehicle.

Rather than the sonic sampling in hip-hop or dub, Akomfrah infuses this logic of ancestor worship into the film medium through bricolage. By layering "official" archival images (Figure 4), "unofficial" narratives about black history, and interviews with living black creators, Akomfrah creates a seemingly do-it-yourself production with the technologies at hand. The film performs ancestor worship using a methodology of excavation and a bricolage aesthetic in order to reanimate the formerly fragmented history into a culturally specific composite that transports viewers into a collective consciousness and communal set of future-oriented practices. In other words, the assemblage of fragments creates a black (w)hole that incorporates the official and unofficial but goes beyond the categorizations to imagine an alter-destiny, a heterotopia for African diasporic subjects where they can piece together an identity consistent with their respective genealogies. Houston A. Baker's term applies to Akomfrah's larger project in that it creates "a new order of existence" that attempts to assemble an impossible wholeness through a blues rite of passage. Baker explains that central to this progression is the stage in which the "initiand grasp[s] his own black timely timelessness through receipt of ancestral wisdom, he negates a dominant society's perceptual schemes by re-(w)riting and (righting) history" (Baker, 154). Like Foucault's heterotopia, the black (w)hole is not overtly utopian because it acknowledges the inherent rupture within black (w)holeness, yet contains within it the utopic possibility of "righting" history. In 
order to perform the "re-(w)righting and (righting) of history," one has to inhabit the interstitial spaces between the binary oppositions, the liminal spaces between wholeness and rupture, official and unofficial, black and white, and past, present, and future. As such, Akomfrah creates a vault of racial memory in his film through which the data-thief and the viewer discover methods, tools, and techniques for revising history and their respective places within it. The film provides a chronopolitical foundation to imagine an alter-destiny for the present based in the understanding of wholeness as always in the process of becoming (real).

\section{Learning the lexicon to hack the script}

The film operates on numerous different levels to simultaneously produce, record, and broadcast ancestral knowledge to the viewer. In a quasi-documentary style, Akomfrah elicits black speculative writers, artists, and musicians to reflect on their artistic styles and remember their influences. Like the viewer, data-thief watches these interviews in a representation of an Internet vault (Figure 5). The data-thief, then, hyperlinks out to other individuals and places as his search continues. In one such instance, George Clinton says, "space for black people is not something new. I believe we've been there, we're returning there...we're always striving to return where we came from" (Akomfrah, 10:04 - 10:24). While this could be seen as a performative, almost ritualistic display of Clinton's funky futuristic aesthetic, the film then teleports into an interview with Bernard Harris Jr., the first African American man in space. As the individual who realized Clinton's imagination of a future in which black people exist in space, Bernard Harris Jr. acknowledges the history to which Clinton alludes in the phrase "space for black people is nothing new" and adds a historical thickness to his proposition, 
explaining that Africans were the first mathematicians and expert cosmologists. ${ }^{23}$ The inclusion of Bernard Harris Jr. in The Last Angel of History flattens chronology and materializes the theoretical notion of future-oriented ontologies. In announcing the reality of his ascension into space as well as the fact that science fictional representations of black people in space inspired his trajectory, the imaginative leaps made by Clinton, Sun Ra, and Lee Scratch Perry appear a bit more grounded. In other words, the allegorical tools that Afrofuturists envision have material consequences on individuals' perceptions of themselves and their alter-destinies in the future. Just as a young black creative could watch the film and hope to become George Clinton, Derrick May, or even the filmmaker, one could also watch the film and aspire to become an astronaut. In building a fictional world in which imaginative possibilities overlay material achievement, The Last Angel of History encourages viewers to experiment with the ontological frameworks and aesthetic tools it records and transmits. Akomfrah's archive demonstrates that the future-oriented performances offer ways to negotiate, hack, and reshape one's place in the world. Like the vehicles that figure heavily in Afrofuturist cosmology—-the Black Ark, Mothership, and Arkestra- Akomfrah shows how Afrofuturism itself is a machine for transportation and transformation. Specifically, Akomfrah renders the data-thief's search in a way that allows the viewer to learn the tools, aesthetics, and grammar of the Afrofuturist language. The viewer becomes a participant in the data-thief's project to collect technofossils because the film's composition places the viewer and the narrator in the same subject position as the data-thief. The pinnacle of this overlap between the thief, narrator,

\footnotetext{
${ }^{23}$ The earliest physical evidence of astronomical and cosmological thinking is a lunar calendar found on a bone fragment in Sub-Saharan Africa dated at about 20,000 BC. Late megalithic structures with astronomical purpose appear in Africa and Europe around 5,000 BC (primitive versions of the famous Stonehenge complex in Britain) (Strobel, 2015).
} 
and viewer occurs when the data-thief records new words into his/her memory, timetravellers log, or browsing history. In one instance in particular, the narrator lists a catalog of terms after a series of clips from the documentary-style talking heads: "new words: sonic warfare, sonic Africa, digitized diaspora, Afrofuturism, analogue ecology..." these words highlight concepts from the interviewees for the data-thief and the viewer. The use of "new words" indicates an elision between the narrator and the data-thief, a layering of subjectivity that reveals their mutual labor in creating the films narrative and thematic arc. The narrator ceases to be the objective mouthpiece relaying the narrative framework and becomes an active participant in the information the datathief uncovers. The list of terms functions as quotations or hyperlinks within the film that create a network of relationships between the narrator, data-thief, viewer, and the other subjects, all of which mutually constitute one another. Like the data-thief, the viewer is an individual who travels through time from the future to collect events from the past in order to understand the potential value of the film for the present moment (and future). This suggestion underscores the indoctrinating undercurrent within the film's project. As Akomfrah writes in the film's script: "this past, our present, could be the key to making sense of the future, the present of some yet unborn black person" (Akomfrah, 1993). In this way, the film presents itself as a vehicle—-much like Sun Ra's Ark or George Clinton's Mothership - that contains counterhegemonic object lessons through which the viewer can learn new words and deploy them in a way that reimagines the lexicon of objectification and essentialization already embedded in the source code of how the contemporary technoculture views black bodies. 
The data-thief's linguistic focus stems from a semiotic understanding that language constructs reality; therefore, the new words function as technological innovations, tools that can help people of color tap into the collective racial memory as well as create alternative representations that expand the possibilities for people of color infinitely and to infinity. In a recent exhibition at the New York Public Library called Unveiling Visions: the Alchemy of Black Imagination, the curators cite The Last Angel of History as an inspiring text: "it's within the spirit of this avatar that the curators are operating. Their method is not a direct representation, but rather a critical interpretation through the lens of black speculative cultural production.... The Data Thief is a story that represents what many people are seeking today: a history, a purpose, and a connection to the past that informs our collective future. ${ }^{24}$ Just as the data-thief reaches back to the African diasporic past to discover the keys to his/her future, the curators of the exhibition attempt to piece together a new future archive and update it for the contemporary moment. However, characteristic of the practice that feeds a future-oriented ontology into the present moment, the curators, like Akomfrah, envision their curatorial work as one that will help exhibit-goers navigate "what many people are seeking today," namely belonging. As I will argue in the next chapter, Octavia Butler's novel Parable of the Sower develops this notion of the individual's quest for belonging in an analog network of person-to-person community building. The larger Afrofuturist project to shape the tools of one's liberation and assemble one's community requires one to hack the seemingly fixed sociolinguistic technology of exploitation and codification of history. Like the data-thief, Afrofuturists steal these units of technocultural programming to

\footnotetext{
${ }^{24}$ See the digital brochure for Unveiling Visions: the Alchemy of Black Imagination at http://www.nypl.org/unveiling-visions-brochure
} 
invent, engineer, and innovate spaces, codes, and histories in order to get beyond the limitations imposed by essentialized notions of race, gender, and sexuality. However, by no means are these representations "post-racial." Afrofuturists dive deeply into the subatomic particles of race in order to push its (il)logic to the discursive limits. By hacking race as a technological construct, Afrofuturists, like the data-thief, learn a new lexicon for alternative representations of blackness.

\section{Conclusion}

In his work African Modes of Self-Writing, Achille Mbembe provides the theoretical apparatus to describe the practice of creative authorship to which I have alluded in my discussion of Akomfrah's film and which I will develop in detail in the next section. Mbembe formulation foregrounds the generative potential of creative authorship for African diasporic subjects:

They have to narrate the self and narrate the world, approaching this world from a position in which their lives, their work, and their way of speaking (language) are scarcely legible, enveloped as they are in ghostly contours. They have to invent an art of existing in the midst of despoliation - even though, by this date, it is almost impossible to reenchant the past and cast a spell upon the present (except, perhaps in the syncopated terms of a body that is constantly made to pass from being to appearance, from song to music) (Mbembe, 262).

Mbembe sutures the reality of trauma, invisibility, and marginalization of African diasporic peoples with the possibility of creative authorship to reimagine, reinvent, and reinvigorate such subject positions, if one understands social constructions as mutable. The first part of Mbembe's quote illustrates one of Afrofuturism's central projects, 
namely to write oneself into legibility through the "ghostly contours." As Akomfrah's work demonstrates, Afrofuturism manipulates chronology and reanimates history to do the work that Mbembe sees as "impossible." In projecting African disaporic history into the future, Afrofuturist works create an alter-destiny and a virtual space in which to reframe, hack, and reformulate the past traumas, the official histories, ideologies of "progress," and the anxieties of any given present; in writing oneself and narrating one's world, albeit in a futuristic register, Afrofuturists do not simply "invent an art of existing," but rather forge the tools to create a machine for transformation (Mbembe, 262). As I will demonstrate in the next chapter, the Afrofuturist "art of existing" creates spaces where people of color can do more than exist or survive.

Through the act of creative self-writing, Afrofuturists go beyond critique of the constraining structures such as race, gender, sexuality, and history in order to sketch alternative modes of being in the world. What may seem like frivolous future imaginings in far off worlds in fact delivers a set of rituals and techniques for the present moment. In this way, Afrofuturism is a machine for transcendence, but in no way is it escapism. It provides the aesthetic tools to construct a collective consciousness, a culturally specific, future-oriented mode of being in the world, for a postlapsarian state of fallen angels, failed states, and post-industrial wastelands in which reality is not stranger than science fiction because it is a science fictional reality. 


\section{CHAPTER 3:}

\section{Shaping a More Practical Utopia in Parable of the Sower}

At a critical moment in Octavia Butler's 1993 dystopic novel, Parable of the

Sower, the main character assumes her father's role as preacher after he goes missing in the hellish landscape outside her walled in community:

I preached from Luke... the parable of the importunate widow...A widow is so persistent in her demands for justice that she overcomes the resistance of a judge who fears neither God nor man...Moral: the weak can overcome the strong if the weak persist. Persisting isn't always safe, it's often necessary (Butler, 124).

The protagonist attempts to preach an uplifting moral regardless of the fact that her sermon is most likely a eulogy for her father. However, the moral praises neither God nor religion's capacity for deliverance. Instead, she focuses on an individual's potential to change his or her circumstances through determined action in the present moment. In her opinion, religion does little more than comfort people that God will ultimately lead them down a righteous path. Instead of a hierarchical belief system with a set of instrumentalized tenets for an intended result (if you follow religion's teachings, then you will go to heaven), the protagonist transubstantiates God into matter-to-be-shaped. As a result, God transforms into something akin to Nature-a non-hierarchical presence or a universal constant that one must learn to give-on-and-with in an ethical way, rather than grasp with a false notion of mastery. In this way, religion ceases to comfort and instead necessitates action.

When the protagonist perceives an unresolved feeling settling in the room after she delivers her moral, a woman begins to sing an old song and the community joins in 
chorus: "we shall not be moved..." (Butler, 124). Though cathartic for her community, the protagonist eschews the polyphonic refrain because it turns to an irrecoverable past characterized by collective action for civil rights and community uplift, which she considers at odds with the present reality of their collective situation. Observing the dysfunction and increasing fragmentation of her gated suburban community, she writes, “as much as I want all that I said to be true, it isn't. We'll be moved, all right. It's just a matter of when, by whom, and in how many pieces" (Butler, 125). In Parable of the Sower, the future does not promise an arrival at radical equality in that large corporations bond poor black and brown bodies to debt slavery in fields, factories, and households. However, Octavia Butler uses her protagonist to sow utopian possibilities into an otherwise dystopic near future space. Inventing a belief system, a book for the living, based in the notion that God is Change, the protagonist writes herself into the world and theorizes a mode of being that shapes the confining structures of religion, nationalism, and embodiment. As such, Butler's Parable shows the power of persisting, the way it reformulates hierarchical structures and enacts change across differences based in race, gender, class, age, and ability.

In this chapter, I investigate Parable of the Sower's rendering of religion, time, and authorship in order to demonstrate how the process of creative authorship can transport even the most marginal bodies into a position of power and transform even the most dystopic landscape into a budding utopia. As the initial anecdote suggests, Parable of the Sower does not privilege the miraculous or divine. Instead, it demonstrates the potency of human authorship, adaptability, and empathy to forge what Édouard Glissant 
calls "relationality," ${ }^{25}$ mutual dependence and interpersonal relationships rather than the supremacy of blood, geographic location or nation. By the end of the novel, the protagonist discovers a new language, one that has always been rooted in her biology, yet has been suppressed, silenced, and stigmatized. Butler builds a world in which the iterative process of authorship unfolds in the present tense; the protagonist writes over and writes through trauma and transforms vulnerability into a radical methodology for building community, survival, and repair across difference. Two main theorists inform my discussion of Butler's work. Édouard Glissant's writing informs Butler's imagination of a multicultural, interdependent community in that it exemplifies what he calls a "relational identity" that eschews the totalitarian root structures of land ownership, violence, and foundation myths. In African Modes of Self-Writing, Achille Mbembe theorizes about how creative self-styling and fluid notions of time help to address the fragmented identity of African diasporic subjects. His charge to "reinterpret subjectivity as time" provides a generative avenue to through which to approach Butler's larger Afrofuturist project. Like the data-thief's excavation of the historical archive to create a vault of racial memory, the nascent prophetess in Butler's novel unearths the rooted structures within religion, science, and nationalism to disseminate a non-hierarchical system that encourages action in the present moment. As a result, Butler's protagonist founds a community with alterity as a foundational component; however, by no means is it post-racial or sentimentally multicultural. Rather, it is a community without guarantees based in the continual negotiation of the terms of membership, which in turn breaks down the superficial and confining structures that typically dictate membership.

\footnotetext{
${ }^{25}$ Édouard Glissant's Poetics of Relation heavily informs my discussion of Parable of the Sower. His work will receive extensive treatment below. See Édouard Glissant trans. Betsy Wing. Poetics of Relation. Ann Arbor: University of Michigan Press, 1997
} 


\section{Writing future projections}

Published in 1993, Butler continued to build and rebuild the world of Parable of

the Sower, its award-winning sequel Parable of the Talents, and the unfinished Parable

of the Trickster until her untimely passing in $2006 .^{26}$ In the fictional Los Angeles of 2024,

Butler's world has a neo-fascist President, an ecologically disastrous California hell-

scape, and gated suburban communities that leave the poor to choose to either fend for

themselves in a violent and exploitative landscape or succumb to the debt slavery of agri-

business corporations. In the novel, a meth-like drug called "pyro" causes senseless

violence in the region often in the form of self-immolation or arson because watching fire burn heightens the users' high. Butler, who was born in 1947 and raised in California, would have witnessed the Watts Riots at age 18 and re-lived the public unrest, police brutality, and racial tensions that would erupt again decades later during the Rodney King riots of 1992. In this way, the image of L.A. burning was perhaps emblazoned into Octavia Butler and her generation's collective imagination, making the futuristic hell scape in Parable of the Sower a projection grounded in the very real violence of the time.

The novel follows a young black girl, Lauren Oya Olamina, who constructs a set of religious tenets to deliver a practical approach to the deteriorating world around her. Lauren has "hyperempathy syndrome," a condition that cripples her whenever she sees someone else experience physical pain. Throughout the bildungsroman, Lauren discovers a religion called "Earthseed," and authors its foundational text, Earthseed: the Books of

\footnotetext{
${ }^{26}$ Parable of the Sower was nominated for the Nebula Award for Best Novel in 1994, an award that its sequel Parable of the Talents would win in 1999. However, some critics maintain that the Parable series solidifies Butler's fame as a writer. In 1995 she became the first science-fiction writer to win a John D. and Catherine T. MacArthur Foundation "Genius Grant." Though unfinished, the notes for the third installment of the Parable series are available in fragments at the Huntington Library in San Marino, CA.
} 
the Living, within the pages of the novel itself. ${ }^{27}$ Some of the religion's foundational principles include "God is Change," and "the destiny of Earthseed is to take root among the stars." Like the data-thief's assemblage of official and unofficial histories in The Last Angel of History, the protagonist of Parable of the Sower takes fragments of mainstream belief systems and develops a new language, an alternative future-oriented ontology to address the circumstances of her present moment. Lauren's radical belief is to accept change as a universal constant and to work to shape it in the present in order to arrive at a desired future, rather than attempt to return or recover an always already foreclosed past. In the course of the novel, violence destroys her home and exiles Lauren and the only other survivors, Harry and Zahra. In their attempts to find a safe place, Lauren dresses like a man as a safety precaution, takes in those most vulnerable in the violent landscape, and proceeds to found a community that includes the women, children, and disabled individuals who were subjected to debt slavery by large agri-business conglomerates. Butler's vision speaks to the uncertainty, frustration, and overwhelming feeling of impotency in curtailing the civil unrest, displacement, and violence surrounding race relations in the 1990s and into the present moment; however, she also sows hope for the future if one cultivates the right seeds. In her work, Butler attempts to show that even the most invisible, vulnerable, individual— the black, female, and disabled subject—can write herself into the world, alter the way others see her, and change her immediate surroundings through creative authorship, sharing, ${ }^{28}$ and an orientation toward the future.

\footnotetext{
${ }^{27}$ Lauren emphasizes the fact that she did not invent Earthseed, but discovered it: "I've never felt that [Earthseed] was anything other than real: discovery rather than invention, exploration rather than creation." (Butler, 72)

${ }^{28}$ As I will explicate in more detail, sharing has a number of valances. It refers to the sharing of another's pain inherent in Lauren's hyperempathy syndrome; those with hyperempathy syndrome are called "sharers." I also intend to use "sharing" in the sense of dissemination and mutual construction. Lauren
} 
More broadly, Butler's work speaks to the historical experiences of people of color and extends their plight into a future space in order to dissect and reassemble the machinations of racism, objectification, and exploitation as a new machine with a radically different logic.

In many ways, Parable of the Sower engages in the scientific method in that Butler observes phenomena occurring in her world in the 1990s (modern day slavery, private prisons, drug addiction, global warming, and statistics on illiteracy in America), ${ }^{29}$ proposes a hypothesis (if a young girl writes down everything she believes in a composite religion, then she will find a place in the world and maybe help others along the way), performs an experiment to test the hypothesis (Lauren attempts to found a community based on her belief system), and publishes it so that others can replicate the experiment. With this in mind, I argue that Butler does more than simply use the controlled conditions of the dystopic novel to engage in intellectual thought experiment. She also outlines a set of tools to be used to reformulate, reconceive, and reshape the dystopic realities and traumatic experiences playing out in the present moment to potentially utopian ends. These tools include authorship, empathy, and future-oriented ontologies, yet their operation requires a set of ethical and interpersonal tenets based in creative self-writing and relationality.

After the exiles from Lauren's community migrate north, taking in families, orphans, and former debt-slaves along the way, they settle in a dilapidated house off of

shares her Earthseed verses with her peers, yet it is not a lecture or a sermon because the listener's input feeds back into Lauren's writing.

${ }^{29}$ In her paper "Devil Girl From Mars," Butler discusses Parable of the Sower's inspiration, the fact that it "grew out of [her] being a news-junkie" (Butler, 1998). She points to these events as particularly significant. (http://web.mit.edu/comm-forum/papers/butler.html) 
Highway 101 and found a community called Acorn. ${ }^{30}$ The novel concludes in the past tense, with a collective remembering session in which the characters from various geographic, ethnic, and socioeconomic backgrounds honor those they have lost through words from Bible passages, Earthseed verses, bits of songs, and poems. In collectively remembering, they perform what Achille Mbembe would call self-stylizing. Though he considers the "recovery of the self" a doomed project, Mbembe leaves room for the possibility of creative self-writing to represent the "thickness" of the African [diasporic] present: "only the disparate and often intersecting practices through which Africans stylize their conduct and life can account for the thickness of which the African present is made" (Mbembe, 273). Mbembe cites rituals and celebrations as a set of disparate practices that works to build community across difference. Mbembe writes how "religious practice is becoming the site where the networks of new, non-biological relationships among members of a family or even an ecumene are formed, at the same time as notions of divine sovereignty and patronage are transformed and new dogmas emerge" (Mbembe, 270). While Mbembe describes a practice not dissimilar to the way in which Earthseed envisions new logics through which to cultivate community, he also critiques the hierarchical ground from which its roots grow into networks. In other words, the Earthseed community's funeral rites crystallize the work of the novel as a whole to reconceptualize the notion of time in relation to collective memory and shared subjectivity in order to break down and get beyond the categorizations that define and confine racialized subjects. In this ritualized zone, the Earthseed community exemplifies

\footnotetext{
30 "Earthseed is being born right here on Highway 101-on that portion of 101 that was once El Camino Real, the royal highway of California's Spanish past. Now it's a highway, a river of the poor. A river flooding north" (Butler, 223).
} 
what Houston A. Baker calls a "black (w)hole" or "a new order of existence" created through a transformative process of timelessness, connection with one's ancestors, and a "re-(w)riting and (righting)" of history (Baker, 154). Though these individuals come from African American, Caucasian, Hispanic, and Asian backgrounds, they share their respective historical traumas and acknowledge the sacrifice of their ancestors and direct kin. They form their subjectivity together through relationality, radical alterity, authorship, sharing, and empathy in order to not simply subvert the root structures of hegemonic identity and to imagine an alternative future for their community in the stars, but also to transform those oppressive structures into tools that will build the imagined future space.

Throughout her prolific career, scholars have continually returned to Octavia Butler's work. Most recently, activists have married Butler and Afrofuturism with the lens of social justice, perhaps indicating the fruitful lessons in her Parable for imagining alternatives to racial inequalities and exploitation. ${ }^{31}$ The fact that scholars, critics, and activists $^{32}$ use Octavia Butler's oeuvre to navigate moments of ontological crisis indicates the number of productive frameworks Butler sows into her work. Much like Lauren Olamina and her verses in Earthseed: Books of the Living, Octavia Butler uses her words to cultivate hope for the future and to encourage others not only to imagine alternatives,

\footnotetext{
${ }^{31}$ Since her untimely passing in 2006 , there have been numerous conferences, anthologies, and special journal issues dealing with her work such as a 2006 conference honoring her legacy, a special issue of Utopian Studies (vol. 19 no. 3, 2008) an anthology published in 2015 called Octavia's Brood: Science Fiction Stories from Social Justice Movements, a conference at Spelman College to mark the tenth anniversary of her death, and an ongoing project called Radio Imagination at the Clockshop in Pasadena, California (see appendix Figure 6).

${ }^{32}$ Activists have turned to Afrofuturism as a resource for social justice workshops and lectures such as "Ferguson is the Future: Incubating Alternative Worlds through Arts, Activism, and Scholarship," "Black Super Heroes, Heroines, and Social Justice," "Speculations: Science Fiction, Chronopolitics, \& Social Change," as well as collections like Octavia's Brood: Science Fictions Stories from Social Justice Movements, and the Transformative Justice Strategic Science Fiction Reader.
} 
but also enact them. A document from 1988 recently uncovered in the Octavia E. Butler papers at The Huntington Library in California demonstrates how Butler herself engaged in this practice. Scribbled on the back of a notebook, Butler penned "I shall be a bestselling writer...this is my life... so be it! See to it! I will find the way to do this!" It continues, "I will help poor black youngsters broaden their horizons... go to college... go to Clarion or other writer's workshops... I will get the best healthcare for my mother and myself...my books will be read by millions of people! So be it! See to it!" (Figure 7).

\section{Shaping change through future-oriented ontologies}

Lauren shapes God through the act of writing; yet, authorship is not simply a coping mechanism amid violence, exploitation, and destruction, it also offers a way to relate to others in a world devoid of interpersonal connection. As such, the creation of Earthseed represents a textual extension of Lauren's hyperempathy syndrome. Through the process of writing Earthseed, Lauren reconciles with her doubly vulnerable position. ${ }^{33}$ She carves a space for herself and others who suffer from a disease that has no external manifestations, but is often co-opted as a way to make non-normative bodies into better slaves. At the peripheries of Lauren's narrative, the reader learns that agribusiness conglomerates employ a system of debt-slavery reminiscent to sharecropping. For remuneration, these neo-slaves receive company scrip, but the company charges them for housing, food, and clothing. Typically, wages are insufficient to cover all the expenses, so the workers must continue to work off the debt they had accrued. If they refuse to

\footnotetext{
33 In the merciless, unsympathetic world, her status as a woman and woman of color already puts her in a position of vulnerability to be attacked on the road or abducted to be forced into slavery. Her added biological disability of feeling others' pain augments her precarious position for two reasons. The first, she becomes paralyzed when she feels others pain, which makes her an easier target in the skirmishes that develop throughout the novel. The second reason is that as the reader learns at the end of the novel, people with hyperempathy syndrome make more desirable slaves.
} 
work or cannot pay, they are arrested, jailed, and given back to their employers. The agribusiness companies also prey on those who also suffer from hyperempathy syndrome as their disability makes them easier to discipline. Lauren's project to write herself into existence establishes a productive ontological framework through which she can practice radical empathy, creatively fashion a future for herself and others in order to persist in the present moment amid paralyzing trauma, ever-present violence, and perpetual exclusion. This process re-presents the slave's position as always already modern and reaffirms the black subject's mastery of the technologies of control; specifically, how the black subject must continually repurpose, reinvent, and hack the technologies of control for individual, communal, and cross-cultural uplift. ${ }^{34}$ In this way, a future-oriented ontology destabilizes the narratives that structure time and history in order rebuild them with non-hierarchical logics.

The notion of future-oriented ontology is a tripartite system comprised of the layered relationship between past, present, and future. A reductive division of this framework would describe the interconnectedness of past, present, and future as presentpast, future-present, and past-future. Present-past refers to the way the past invades the present in the form of an essentialized view of the past; often times, this reveals itself in political rhetoric that idealizes past glory, wealth, and geopolitical potency. ${ }^{35}$ Futurepresent aligns most fittingly with what might be considered a future-oriented ontology.

\footnotetext{
${ }^{34}$ See Ian Baucom. Specters of the Atlantic: Finance Capital, Slavery, and the Philosophy of History. Durham: Duke University Press, 2005 and Paul Gilroy The Black Atlantic: Modernity and Double Consciousness. Cambridge, Mass.: Harvard University Press, 1993.

${ }^{35}$ The political slogan "Make America Great Again" compresses all three of these categories, making it a highly effective rhetorical strategy. It uses the presumption of past greatness to render the present as lessthan great; yet its project extends into the future because the process of making America great again takes time. Only a vote in the present will ensure its realization (in the future). In this way, the result would be a past-future; an impossible return to pastness in the re-enactment or repetition, evinced through the word "again," of the "great" American past.
} 
Specifically, it entails a view of the future feeding back into an understanding of the present moment; for example, one might consider the possibility of terraforming Mars to make it inhabitable for humans as a reason advocate for NASA funding. More simply, one's investment in a company's future-shares on the New York Stock Exchange encapsulates the notion of future-presentness. Past-future imbues historical understandings into future imaginaries; this might render the history of eugenics and social Darwinism as genetically engineering human-alien hybrids as Butler does in her Xenogenesis series. In Parable of the Sower, a future-oriented ontology marries the delineations between past, present, and future in a distinctly Afrofuturist way; Butler exposes the false narrative of America's past glory and the impossible return to any essentialized home (present-past). By incorporating the history of slavery (past-future) into her novel, Butler shows how a future-oriented ontology that projects the destiny of people of color into the stars creates a new script for action that can occur in an unfolding present moment (future-present).

In the early stages of the novel, Lauren responds to her stepmother's nostalgia for L.A.'s city lights, or rather, what the lights signify. Stargazing one night within the community's high concrete walls, Lauren's stepmother longs for “city lights...lights, progress, growth" (Butler, 5). The elision between "city lights" and "progress" encapsulates a present-pastness that not only equates metropolitan life as superior to their present state, but also whitewashes the history of Los Angeles as a contested space divided along racial and socioeconomic lines. Instead of the "city lights," Lauren says, "I'd rather have the stars," a future-present orientation that directs her action throughout the ensuing novel (Butler, 5). In a similar instance, Lauren and her father discuss the 
ongoing electoral campaign, in which presidential candidate Christopher Morpeth Donner plans to enact free-market economic policies that will exacerbate the ongoing system of debt slavery; he also wishes to abolish the Mars space program. Lauren says:

Politicians have been promising to return us to the glory, wealth, and order of the twentieth century ever since I can remember. That's what the space program is about these days, at least for politicians. Hey, we can run a space station, a station on the moon, and soon, a colony on Mars. That proves we're still a great, forward-looking, powerful nation, right? (Butler, 20)

Like her stepmother's compression between the city lights and what they represent, politicians similarly conflate the exploration of space with an essentialized notion of “progress.” Conversely, Lauren believes "space could be our future” (Butler, 20). Though politicians code the space program as "forward-looking," Lauren reveals the project as inherently past-oriented (Butler, 20). Rather than a future-oriented project to create a human colony on Mars, the space program is a symbolic endeavor intended to represent America's "modernity" and power. In other words, the space program in 2024 is no different than the space race of 1964; a symbol of technomastery intended to solidify the myth that technological innovation, or "progress," signifies superiority in the geopolitical world order. In this way, modernity becomes a teleological progression that is both spatialized and temporalized as an occupation of discursive and symbolic power that asserts future-ness dialectically and temporally opposed to tradition, pastness, and impotency (Figure 8-9). ${ }^{36}$

\footnotetext{
${ }^{36}$ See James Ferguson. Global Shadows: Africa In the Neoliberal World Order. Durham [N.C.]: Duke University Press, 2006.
} 
In contrast to the politicians" "forward-looking," but paradoxically backward gaze, Lauren's vision is progressive without being hierarchical. She would rather have what the stars promise than what the nostalgia for city lights mistakenly attempts to recover; she would rather have the space program than what the rhetoric about the space program recapitulates. Yet, while she provides incisive critique and a visionary pragmatism, the authority figures do not take her seriously because of her position in society as a young woman; she is a Cassandra figure who predicts her community's destruction. She prophesizes the breach of the neighborhood walls, the fire that will consume her community, the election of Donner, his closure of the space program and extension of economic policies that fuel the practice of debt-slavery; however, like Sun Ra's mantra echoing in The Last Angel of History ("it's after the end of the world, don't you know that yet") no one heeds her warnings. For Lauren, space is heaven "in a way," not in an ethereal realm of perpetual life, but as a practical alternative, "a whole other world...within reach of the people who've made such a hell of life here on Earth" (Butler, 21). As such, Lauren's future-oriented ontology neither destroys the existing hierarchical structures, nor attempts to start over; rather, it imagines the proper rhetorical machine to inspire the action that will ultimately transport people to the heaven "within reach" (Butler, 21). Lauren imagines a future space, in which the contradictions, injustices, and destruction of the present might take another form, and acts in the present moment to assemble a way to survive amid certain disaster. In so doing, Butler avoids pedantically rebuking "social constructions." Instead, she crafts a character that creatively shapes the raw materials around her to construct different structures, rather than watch them burn. 


\section{"God is power... and yet"}

Lauren utilizes the act of writing to build her own belief system and by extension cultivate a practice of empathy and mutual uplift for those around her. ${ }^{37}$ Lauren assembles a future-oriented ontology from pieces of mainstream belief systems, stemming first from her familial ties to Baptist Christianity. In one distillation of this practice, Lauren enumerates the hierarchical potency of religion, but turns on the word "yet" to imagine an alternative:

\section{God is Power-}

Infinite,

Irresistible,

Inexorable,

Indifferent.

And yet, God is Pliable-

Trickster,

Teacher,

Chaos,

Clay.

God exists to be shaped.

God is Change. (Butler, 24)

In the first half of the verse, God represents the seemingly authoritative presence of religion as a structure of power that exists beyond the scope of the individual's agency. The conjunction "and yet" implies that the emphasis on authority belies religion's

\footnotetext{
${ }^{37}$ Consistent with her non-hierarchical, grassroots logic, Lauren wants to put the collated verses from her journal into "exercise notebooks" to be used in local schools, rather than assemble Earthseed into a dogmatic religious text.
} 
potential to be practical in everyday life. In asserting, "God is Pliable," Lauren alters the physical properties of religion from formerly solid and confining to malleable and thus open to other uses including education, play, and infinite randomness. As such, God becomes a technology capable of being deconstructed and reconstructed through an individual's language and actions. In other words, power is the source code of religion; it preprograms behavior and dictates the interface between the individual and God. Lauren decrypts the false narrative of God's fixity to repurpose, hack, and re-present God as perpetually amorphous. Like shaping clay, Lauren writes and analyzes, revises and rewrites, throws away and keeps, shares and tweaks these Earthseed verses until they are ready to share. At first, Lauren writes down and analyzes by herself, but as the novel progresses, she shares verses with individuals, who in turn provide feedback; this peer-topeer model expands to group sessions on the weekends, until the verses can stand alone, outside of Lauren herself, and others can take ownership of them. In this way, Earthseed develops organically and characterizes what Édouard Glissant describes in Poetics of Relation as "relationality" in that Earthseed "is produced in the chaotic network of Relation" that "gives-on-and-with ${ }^{38}$ rather than grasps" ideological territory and power (Glissant, 144).

The notion of "relationality," as it pertains to what Gilles Deluze and Felix Guattari call "the root" and "the rhizome," maps onto Lauren's narrative of exile and cultivation of a community through authorship and empathy. Glissant describes Deluze and Guttari's concept of the root and the rhizome as:

The root is unique, a stock taking all upon itself and killing all around it...The rhizome [is] an enmeshed root system, a network spreading either in the ground or

\footnotetext{
38 donner-avec
} 
in the air, with no predatory rootstock taking over permanently. The notion of the rhizome maintains, therefore the idea of rootedness, but challenges that of a totalitarian root. Rhizomatic thought is the principle behind what I call the Poetics of Relation, in which each and every identity is extended through a relationship with the Other. (Glissant, 11)

Earthseed exemplifies what Glissant describes as "rhizomatic thought" in that the belief system “enmeshes" various "root systems," including Christianity, Buddhism, existentialism, Sufism, and scientific knowledge, to offer a person-to-person practice of empathy that resists the predatory aspects of its constituent parts. For example, Lauren creates Earthseed as a response to her parents' and community's atavistic longing for a return to "normal," namely a foreclosed past associated with nationalism, conquest, and the violence of protecting one's territory—key principles in Glissant's framework of "root identity." ${ }^{39}$ She samples aspects of "Root" structures such as civilization, religion, and science in order to theorize a "relational identity" ${ }^{40}$ that provides a vehicle for survival, cross-cultural partnerships, and mutual uplift in the novel's stark, merciless environment. For example, Lauren mirrors the construction of the above Earthseed verse to show the root structures that feed into her belief system:

From the second law of thermodynamics to Darwinian evolution, from Buddhism's insistence that nothing is permanent and all suffering results from our delusions of part of life, of existence, of the common wisdom... Yet God has been

\footnotetext{
${ }^{39}$ One of Glissant's criteria for "Root identity" is an identity that "is founded in the distant past in a vision, a myth of the creation of the world" (Glissant, 143).

40 "Relation identity is linked not to a creation of the world but to conscious and contradictory experience of contacts among cultures; it is produced in the chaotic network of Relation and not in the hidden violence of filiation; it does not think of land as a territory from which to project toward other territories but as a place where one gives-on-and-with rather than grasps." (Glissant 144)
} 
here all along, shaping us and being shaped by us in no particular way or in too many ways at once like an amoeba—or like a cancer. Chaos. (Butler, 25)

The first section lists root structures of physics and social evolution as well as Eastern and Western religion. Again, Lauren includes "Yet" to signal the importance of viewing God, not in terms of the omnipotent, indefatigable, abstraction, but for God's material potential to-be-shaped, and thus chaotic potential to perpetually change. She points out that "change is part of the common wisdom," but argues for a more intentional practice of shaping God (Butler 25). In a dual move between Earthseed verse and analysis, Lauren demonstrates the practice she encourages by sampling generative aspects of theological and scientific texts, while overwriting the legacies of totalitarian root identity in the process. She alludes to this in the phrase "shaped by us...in too many ways." Though innocuous, it recalls the way in which eugenics mobilized Darwinian evolution to enact their project of racial purity. Perhaps the seminal example of Glissant's "root identity," eugenics has a rooted "thought of self and of territory" and "set[s] in motion the thought of the other" as equally essentialized through "discursive knowledge" (Glissant 143). In the novel's world this eugenicist impulse repeats in the system of neo-slavery in which corporate slavers lock people, predominantly the poor and people of color, into a system of debt slavery. The eugenics undertones come into sharp relief when the reader learns that people with hyperempathy syndrome are more desirable slaves because their ability to share the pain of others makes them easier to discipline, instrumentalize, and exploit.

On the macro-level of the novel as a whole, Butler similarly critiques and repurposes the structures of religion to create a text that people can use. In the synoptic gospels of the Bible, the "Parable of the Sower" tells the story of a sower who attempts to 
plant seed on three different terrains: rocky ground, among thorns, and on good soil, when sowed on proper soil, the seed produces a crop that yields a hundredfold. ${ }^{41}$ As the vehicle for the word of God, the seed only flourishes on fertile land, not thorny or rocky ground. The tenor presumes that the good soil, the devoutly religious, will not only understand the word of God, but also propagate it. Having established the rootedness of power within religious doctrine, the dissemination of the word does little to improve the seed or the soil, but serves only to increase the power of the word. As such, Butler uses the framework of the parable to deliver up a non-hierarchical moral based in the redemptive power of the individual and his or her own actions in relation to the community rather than privilege the dogmatic words themselves. She constructs Lauren as a character that exposes the limitations of hierarchical organization and the potential for what can be made in the spaces and traces of these systems. Lauren's Earthseed critiques the hierarchical nature of religious text, desiring instead to build a belief system based on practicality, adaptability, and change as potentially transformative tenets. Furthermore, Butler appropriates not simply the Christological tradition, but also Eastern theology. While the novel uses the biblical parable of the sower as an intertext, Lauren's Earthseed text responds to the tradition of books of the dead, especially The Tibetan Book of the Dead. ${ }^{42}$ According to Lauren, "Earthseed deals with ongoing reality, not with supernatural authority figures. Worship is no good without action” (Butler, 202).

\footnotetext{
${ }^{41}$ In the Gospel of Mark, Jesus explains that the seed on rocky ground refers to those people who hear the word and "immediately receive it with gladness; and have no root in themselves" so that when persecution comes because of the word they fall away; the seed among the thorns alludes to people whose wealth chokes the word; the good soil entails not simply hearing the word, but receiving it, understanding it, and sharing it with the world (Mark 4:1-20).

42 "I've finally got a title for my book of Earthseed verses-Earthseed: Books of the Living. There are the Tibetan and the Egyptian Books of the Dead. Dad has copies of them. I've never heard of anything called a book of the living, but I wouldn't be surprised to discover that there is something. I don't care. I'm trying to speak - to write - the truth" (Butler, 115).
} 
Throughout Parable of the Sower, Butler exposes the hierarchical tendencies of religious belief systems, collective hallucinations like patriotism, and the paradoxical pursuit of "progress." Her alternative comes in the form of a young woman's desire for action and the way in which her pursuit leads to the active construction of self and community. Lauren and Butler attempt to construct an anti-body to the virus of hierarchical root systems that bind African diasporic peoples. The change-based ethics do not stop at critique, but attempt to enact the project throughout the course of the novel. While Butler exposes that which controls and has historically controlled black bodies discursively and materially, she attempts to program different logics based in malleability, adaptability, and perpetual change that deliver transformation. In the process, she hacks the source code of religion, history, and nationalism to show an alternative tradition in which black subjects were always piecing their identities together while alienated, exploited, and commoditized by the dominating system of power. As a result of this reformulation, Butler sows an alternative ethics that takes alterity as foundational principle in order to transcends the strictures of embodiment for raced, gendered, and disabled bodies and build community across difference.

The temporal collapse that presents agribusiness corporations re-enacting the machinations of plantation-era slavery does more than illustrate a moral or historical lesson; it shows that there is no time to wait for persisting inequality to change. As Lauren tells one of her first converts: "there's no power in having strength and brains, and yet waiting for God to fix things for you or take revenge for you" (Butler, 202). Throughout the novel, Butler continually feeds the history of slavery into her futuristic text. In one such instance, Lauren discusses Earthseed with a new member of her group, 
Travis, who Lauren and the other exiles from her hometown help protect along with his wife and newborn child. When Lauren shares an Earthseed verse with him, Travis comments that it sounds like "entropy, the idea that the natural flow of heat is from something hot to something cool—not the other way—so that the universe itself is cooling down, running down, dissipating its energy" (Butler, 200). Seeing Lauren's surprise, Travis explains how his mother would steal books from their employer to teach him how to read and write. "Of course," Lauren narrates, "Slaves did that two hundred years ago. They sneaked around and educated themselves as best they could, sometimes suffering whipping, sale, or mutilation for their efforts" (Butler, 200-201). In another scene, Lauren and her confidant, Bankole, discuss their long-term plans for the community. Lauren observes that the conversation about saving those most vulnerable, women, children, and the disabled from neo-slavery seems like "a modern underground railroad" (Butler, 268). Bankole responds, "none of this is new... in the early 1990s while I was in college, I heard about cases of growers doing some of this-holding people against their wills and forcing them to work without pay. Latins in California, blacks and Latins in the south..." (Butler, 268). These examples compress the fictional future landscape of 2024 with the history of slavery hundreds of years before and the 1990s present in which the book was written. The allusion to the Underground Railroad reframes its history as an inherently futuristic project of assembling community and imagining collective, interpersonal machines to transport enslaved peoples to safety. Community building is an authorial practice and Butler reminds the readers of its long history as a transformative vehicle for African diasporic subjects. While authorship may seem like an individual act, the work of the author in this setting roots itself not in an 
essentialized origin or hierarchical dogma, but rather shared fragments of knowledge, a mélange of experiences and backgrounds, and a multiplicity of ways of knowing, ways of being, and ways of understanding the world. The product is a composite of inherited epistemological, ontological, and phenomenological tools drawn from the range of African diasporic backgrounds. Most importantly, however, the work of the author emerges out of a non-hierarchical relationship within the collective, what Glissant calls "the chaotic network of Relation" (Glissant, 144). Through Earthseed: Books of the Living and Parable of the Sower, Lauren/Butler revise religion to focus on the present, write themselves into a voice and into power, and build a world in which the most vulnerable can shape their destiny for themselves. However, this seemingly utopian project requires constant negotiation and communication about race, ethnicity, ability, and gender. In other words, authorship and "sharing" can create a new language of relation only insofar as the voices, genders, and persons conjugate their existence openly and often.

\section{Sharing seeds for change}

In Parable of the Sower, Lauren's "sharing” is the act of disseminating Earthseed verses as well as an inherent biological difference. While for the majority of the novel Lauren internalizes her biological difference as a disability ${ }^{43}$ that excludes her from

\footnotetext{
43 Lauren's Dad refuses to tie her disability to her identity, choosing instead to see it as a phase she will outgrow or overcome: "He tells me, 'You can beat this thing. You don't have to give in.' He has always pretended, or perhaps believed that my hyperempathy syndrome was something I could shake off and forget about" (Butler 10). As a result, Lauren internalizes her difference as a source of shame, "It's delusional. Even I admit that" (Butler 10). Lauren's Dad attempts to circumscribe her within a conception of normalcy and able-bodiedness without understanding the potential to inhabit the world as a destigmatized body, if properly cultivated.
} 
normative performances, ${ }^{44}$ she begins to destigmatize her disability as an object of difference and shape it into a tool for individual and communal uplift. Creative "selfstyling," as defined by Achille Mbembe, enables Lauren to bridge her "self-division" and "objecthood," terms used to underscore the African diasporic subject's alienation from his or her self, biology, and identity. While her self-styling entails writing the verses to a new religion, Lauren fully discovers a new language when negotiating her identity and difference in the "chaotic network of Relation" (Glissant, 144). In a climactic scene in which drug-induced pyros attack the group's camp, Lauren defends her peers regardless of the pain she will feel due to her hyperempathy syndrome. When she wakes up after fainting from the pain of sharing her attackers' death, the newest member of the group Grayson Mora prompts the discovery of a new language in Lauren:

"How many times did you die?" Mora asked me.

"Three at least," I answered, as though this were a sane conversation. "Maybe four. I never did it like that before - over and over. Insane. But you look well enough.”

His expression hardened as though I slapped him. Of course, I had insulted him. I'd said, where were you, man and fellow sharer, while your woman and your group were in danger. Funny. There I was, speaking a language I hadn't realized I knew. (Butler, 275)

Lauren's apparent new language is that of "dying three times;" however, the subtext reveals the limits of Lauren's empathy. Though Lauren and Mora both have the same disability, Lauren's interpersonal empathy breaks down as she insults Mora for not

44 Therí Pickens also describes Lauren's progression as consistent with the "coming out discourse" which requires one to "construct a specific narrative explaining her body to a skeptical, ignorant, and somewhat hostile audience" (Pickens 171). 
performing the normative gender roles - the men in the group protect the women. Mora reveals that he immediately went to protect his daughter when he saw the oncoming threat. In this way, Lauren's insult functions to inscribe Mora within a hierarchical system of gender signification as well as disavows his position as a fellow sharer. Furthermore, as a new member of the group, a runaway slave who has been exploited for his biological condition as a sharer, Lauren fails to recognize Mora's desire for his daughter's survival as well as the fact that he is conversant in the language of dying multiple times. In asking how many times she died, Mora attempts to empathize with Lauren and bridge what was before an odd tentativeness between the two. Prompting the discovery of a new language, Mora effectually says, "I've been there;" yet, in the chaotic network of relation, Lauren cannot reconcile the gendered differences between them.

After this interaction, however, Lauren begins to negotiate, empathize, and understand Mora's position as a male sharer. She realizes the double bind that a male sharer would necessarily experience, the very same gender-based categorization she exposed: "he did a lot to keep people away from him—keep them from knowing too much about him, keep them from seeing what he was feeling, or that he was feeling anything — a male sharer, desperate to hide his terrible vulnerability? Sharing would be harder on a man" (Butler, 295). This formulation turns on the artificial binary between male/rationality/strength/individualism and female/emotionality/vulnerability/ collectivity. Once Lauren and the larger Earthseed community begin to peel back the binaries preprograming Mora's tentative behavior, they see his compassion, empathy, and capacity for nurturance. Simply put, her action with Mora shows that Lauren does not always practice what she preaches. The relationality Glissant describes as giving-on-and- 
with takes active, repetitive, often mundane work of cultivating relational identity, of breaking down hierarchical structures on a macro level but also interrogating one's person-to-personal relationships on a micro level. More broadly, the communal ties of vulnerability, radical (biological) alterity, and difference are not intrinsic guarantees for membership, but must consistently be negotiated in a relational, rhizomatic logic.

A similar negotiation of difference occurs in the dénouement of the novel along racial and gendered lines. When the migrants arrive at Bankole's family plot off Highway 101 to find Bankole's family dead, the house dilapidated, and the land barren, they discuss if they should stay to stay and build a community or split up. In this context, the characters imagine the possibilities for them in the future and call to mind their respective pasts. However, their differences prove a potentially divisive issue. For example, Emery, who Lauren describes as the most racially mixed person she has ever seen, acknowledges the opportunities afforded to Harry by his whiteness:

"You might be able to get a job as a driver," she said. "They like white men to be drivers..."

"I don't know how to drive, but I could learn," Harry said. "You mean driving those big armored trucks, don't you?"

Emery looked confused. "Trucks? No, I mean driving people. Making them work. Pushing them to work faster. Making them do... whatever the owner says." Harry's expression had dissolved from hopeful to horrified to outraged. "Jesus God, do you think I'd do that! ... Are you telling me you believe I'd like a job pushing slaves around and taking away their children?"

She stared back, searching his face. "I hope not." (Butler, 294) 
Emery exposes the privilege inherent in Harry's whiteness, able-bodiedness, and masculinity. In this example, Butler addresses the potential criticisms of the novel as sentimental multiculturalism in that she shows the characters negotiating the gender, race, socioeconomic background, and able-bodiedness of their peers in an ongoing basis. In this scene, Harry's horror and outrage at Emery's suggestion indicates the fact that membership in the community has no guarantees. Regardless of the fact that he was an original member of the group, coming from Lauren's community after their initial exile, the mobility afforded by the external appearance of his body means that Harry has the capacity to abandon the group for the privilege of his perceived "normalcy" in the larger society. ${ }^{45}$ While this scene does not carry the same historical precedent or dehumanization, Emery's outing mirrors the Fanonian scene of instruction to remind Harry of his racial identity. ${ }^{46}$ This inversion, while not dismantling the hegemonic structures outside of the Acorn community, makes Harry the Other in a community where difference is the norm. Unlike Fanon's inscription into a racialized body while literally in transit this event occurs in a zone of perceived safety, in which the outing of racial category starts a conversation rather than delivers as an authoritative speech act with no response. These negotiations reveal that for all the intersubjective maneuvering and productive formation of relational identities the structures of power persists; Earthseed still remains underground in a period of gestation. In this way, Earthseed practices what it preaches; accepting change as a constant that accommodates difference through the logic of destabilization, destruction, and reconfiguration. This reformulation occurs not as in an

\footnotetext{
${ }^{45}$ Emery's comment also points out that Harry's normative status can be an essential tool to their survival in that his presence legitimize their existence as a group. Through Harry, they can "pass" as a slave driver transporting human cargo. Though it horrifies Harry, his position allows the group to hide in plain sight to continue their modern reenactment of the Underground Railroad.

${ }^{46}$ See Frantz Fanon. Black Skin, White Masks. New York: Grove Press, 1968.
} 
additive process, which retrofits another compartment to the existing structure, but rather as a reassembly of the foundation upon which to construct membership.

To use Butler's framework, the foundation for the ethics based in empathy, sharing across difference, and future-oriented ontologies is a new language. Ato Quayson describes the writing of selfhood as "the process of coming to know oneself, confronting one's contingency, tracking one's causes home, is identical to the process of inventing a new language;" as Quayson aptly notes this entails "thinking up a fresh set of metaphors by which the self can be spoken" (Quayson 100). Lauren's self-discovery occurs in tandem with language formation and the distribution of her belief system in the chaotic network of relation. The key metaphor for Lauren's language is "sharing" because it contains within it the literal act of exchanging information and the figurative act of empathizing with another. Her communication model is a feedback loop or rhizomatic network that oscillates between one-to-one and one-to-many distribution then feeds the output back into the process of self-writing; the rhizomatic logic makes any one center or root impossible to distinguish. However, the process by which Lauren discovers her new language necessitates an acceptance of the loss of self that her hyperempathy-induced "sharing" entails. In dying three times, Lauren fully perceives the artificial boundaries between self and other. It takes a destabilizing experience for her to realize the power of intersubjectivity that was always already there in her biology. Houston A. Baker describes how this process of transformation and reincorporation is essential to black expressive culture, terming it the "black (w)hole" (Baker, 155). Baker outlines a progression from "a fixed social position" through a period of movement and marginality characterized by “(w)riting and (righting) history” as well as timelessness and 
spacelessness, to conclude with a reincorporation into society as a transformed individual. After the rites of passage, he argues, "the black (w)hole is now the center of a new order of existence" (Baker, 155). The metaphor of the black (w)hole, here and for Baker, signifies the generative potential in pushing the limits of the individual body within the social reality preprogramed by the discourses of science, history, and religion. However, the ambiguity of the term through the parenthesis acknowledges the inextricable presence of a foundational rupture for African diasporic peoples. Appropriately, for Houston's blues aesthetic, the new order of existence lies in the suspended chord, in the space between resolution and dissonance. ${ }^{47}$ In this way, the Afrofuturist universe of black signification sutures rupture and harmony, fusion and fission, alienation and connection, science and humanism into a perfect-imperfect machine always conjugating in a past-future future-present world.

Parable of the Sower offers a model of being in the world that projects the destiny of people of color into the future and into space; yet, the novel reveals the rigorous interpersonal work required to form communities that operate through radically different logics, a person-to-person network that resembles grassroots organizing today. Parable of the Sower builds on the legacy of Afrofuturism to create a religious metanarrative in an aesthetic bricolage that overwrites and creatively self-styles - through American nationalism, Christological traditions, scientific theories, Eastern religions, African cosmology — to imagine a new religion more fitting for the multi-ethnic future. It is a visionary example that reflects the contemporary moment for Afrofuturism, in which

\footnotetext{
${ }^{47}$ Here, Foucault's notion of heterotopia encapsulates the interstitial nature of the new order of existence in between the hole and the whole. Heterotopias "are something like counter-sites, a kind of effectively enacted utopia in which the real sites... are simultaneously represented, contested, and inverted. Places of this kind are outside of all places, even though it may be possible to indicate their location in reality" (Foucault, 4)
} 
diasporic narratives and the global south have expanded the genre far from its origins in African American technoculture. Moreover, the novel provides a productive framework for contemporary activists who believe issues of environmental, racial, and economic justice must be addressed in tandem. Yet, the novel does not get mired in invective that decries inequality, racism, and economic exploitation, but rather presents a hopeful, albeit fictional set of tenets through which to achieve person-to-person change. In so doing, the novel eschews the expected narratives of African American literature levied from the publishing establishment, which seeks social realism or fiction that partakes in historical topics. Like Lauren, Parable of the Sower shapes time in a non-linear way to make the near future speak to the present and address the concerns typically rendered in a socially realistic or historical fiction novel. While Parable of the Sower neither represents Butler's most futuristic nor cyborgian, its potency rests in its careful construction of a future that lies outside of the story's frame. It sows the seeds of a future based in radical empathy, relational identity, and an intense commitment to authorship, literacy, listening, and making together with the hope that readers will put these imaginings into practice in the present moment in order to shape a more practical utopia. 


\section{CHAPTER 4:}

\section{Conclusion: Multidimensional Machines to the Future and Back}

At the end of Janelle Monáe’s “Many Moons” video her android alter ego, Cindi Mayweather, experiences a non-technological transformation. Whereas previously she activated her blackness with a button on the side of her head, in this instance, she becomes disembodied and decorporealized through dance and music She floats above the on looking crowd, suspended in a state of timelessness and spacelessness, with ethereal blue liquid emanating in the background, as her body begins to separate into two distinct figures (Figure 10). After she falls to the ground, the android Cindi Mayweather shuts down and appears to die. When the video goes dark, a quote attributed to Cindi Mayweather appears on the screen: "I imagined many moons in the sky lighting the way to freedom" (Monáe, 6:20). In this instance, death and de-animation represent an object lesson to attain freedom at the expense of the commoditizing, exploitative, and dehumanizing technoculture that attempts to program Mayweather's performance. The moment layers the future-time of Mayweather's fictional Metropolis and the presentmoment of viewing the video to show the on looking androids in the music video and the real people watching that they too can hack the preprogrammed scripts of performance for a raced, gendered, and non-normative body in order to transcend the limits of embodiment, space, and time.

Just as there are numerous musical styles feeding into Monáe’s aesthetic, various dance moves she samples from pop-legends, and multiple chronologies that she layers into her fictional Metropolis, there are "many moons" existing on planetary scales in alternate universes contemporaneously. These heterotopias announce the same alter- 
destiny, which is same destiny that Earthseed envisions: to take root among the stars. This future-oriented ontology feeds back into the present tense to deliver a way of being, a way of understanding, and a way of writing oneself into the world. Imagining different routes to freedom, whether through a rhizomatic, relational belief system, a heterotopic vault of racial memory in virtual reality, or the infectious pulse of cyber-soul, these Afrofuturist machines operate to assemble a black (w)hole. The product (de/re)centers the hierarchical structures of race, history, and time. The new machine navigates a space without a center, an interstitial zone, a multidimensional liminal territory in virtual reality, outer space, the human psyche, in the chaotic network of relation. In these unconfined, in-between spaces, the African diasporic subjects can become prophets and angels, leaders who bring runaways, aliens, and outsiders into spaces where they belong.

Though in dystopic futures and virtually rendered reality, these works show prophetic figures that attempt to reverse engineer transformation machines in a preprogramed technoculture seeking to exclude them. By virtue of their existence as avatars on screen and in print, they take on otherworldly proportions. However, the problems and questions that face these characters are not spectacular: the quest for identity, the question of how to belong in a space of alienation, how to live, work, and contribute meaningfully to society in a way that is consistent with one's cultural identity. Akomfrah's virtual reality data-thief, Butler's self-writing prophetess, and Monáe’s soulful android show the transformative potential of inhabiting spaces considered liminal, uncategorizable, invisible, outsider, and alien. In these interstitial, multidimensional zones, an individual with the correct tools can assemble alternative logics, representational vehicles, and transformation machines that rewrite the exclusionary 
source code of hierarchical systems to create a new world order that reimagines alterity as the norm.

More broadly, Afrofuturism offers a conceptual framework that continually pushes its own delimitations and definitions as futuristic signification that attends to African diasporic themes. Its practitioners perpetually hack, decrypt, encrypt, and assemble the "Afro" and "futurism." As such, Afrofuturism is a mobile and mutable machine that travels across genres, disciplines, and geographical boundaries from literature, music, film, visual arts, to critical race theory, ecocriticism, anthropology, sound studies, and queer studies. While my discussion of Parable of the Sower did not address Butler's representation of nature, an ecocritical approach to the novel would be immensely fertile. Such a project might investigate the portrayal of Nature as a corollary to Earthseed's assembled belief system to read the numerous ecological disasters as materials to be negotiated, navigated, and shaped similarly to the religious tenets and interpersonal interactions. A metacritical approach to The Last Angel of History might analyze the curatorial impulse in the essay-film in the context of the larger project to perpetually define and redefine Afrofuturism in exhibitions, anthologies, and creative productions. In other words, the Afrofuturist practice extends well beyond the scope of this project and even attempts to exceed its own codifications.

A brief sketch of contemporary Afrofuturist practitioners demonstrates its wideranging implications across genre, geography, and discipline. In the Caribbean speculative fiction novel Midnight Robber, Nalo Hopkinson envisions in a futurity in which Afro-Caribbean folk stories operate as central nodes within cybernetic networks. Kerry James Marshall paints large-scale canvasses that juxtapose African diasporic 
history and visual culture with the traditions of renaissance iconography. His work unearths submerged histories like the slaves buried below Monticello and Mount Vernon (Figure 11) and imagines black people "Keeping the Culture" of the African diaspora in interstellar space stations (Figure 12). Kenyan filmmaker Wanuri Kahiu sets her short film Pumzi in a post-apocalyptic world where humans attempt to genetically engineer plants in underground colonies having destroyed the natural world outside. In the film, the protagonist dreams of the last tree in the world and sets out into the desert-like landscape to plant the last seed on earth beside it. In the photo project Afronauts, Spanish photographer Cristina de Middel re-presents the lost history of the Zambian science teacher named Edwuard Makuka who launched the Zambian Space program during the heat of the space race in 1964 (Figure 13). De Middel assembles fictional images and archival documents to reanimate this history as an alter destiny of African space explorers-Afronauts with the keys to go to Mars. Kenyan artist Cyrus Kabriu, who makes glasses from electronic waste, literalizes the Afrofuturist project to assemble fragments of discarded technoculture; his creations are assembled machine through which to see the world (Figure 14). Lastly, throughout the U.S. activists have deployed Afrofuturism to organize for social justice, bringing Alondra Nelson's Afrofuturist listserv full circle in the form of Instagram, Tumblr, and Twitter communities. While not intending to praise the social media networks or the technology itself, the way in which online communities such as The Afrofuturist Affair deploy Afrofuturist signification to create a culturally specific space on the Internet demonstrates that even the seemingly commoditized and normative digital networks can be navigated and negotiated in productive ways. Ultimately, the community builds itself outside of digital networks 
themselves in the form of conferences (Figure 15), open-mic events, and self-published zines (Figure 16) that circulate in the chaotic network of relation.

In this way, Afrofuturist imaginaries are neither radically separatist nor adolescently utopian, neither essentializing in their delimitations of a race-based membership group, nor flagrantly "post-racial;" rather, as Afrofuturism expands its scope geographically into the Caribbean, Africa, and even the Asian-subcontinent, it remains meticulously attentive to the tools of transformation as well as the material circumstances and historical conditions of people of color within and in spite of official representations. Afrofuturists enact material change by disassembling the false narrative that the concepts of race, gender, sexuality, nation, and time are structurally sound. Alter-destinies echo in the spaces. Do-it-yourself assemblages emanate from the source code of exclusion to attune would-be Afrofuturists to future-oriented frequencies. The Afrofuturist world of signification encrypts messages within formal texts that overwrite without overriding the normative structures themselves in order to hide in plain sight as a virus that gradually takes over the host. These future machines plug in the sonic, psychic, textual, and interpersonal coordinates that will transport the alien, android, or outsider to a space of belonging in virtual reality, outer space, or some yet-unrealized future. In this transformed world, the visions of the future include the specters of the past and reconfigure the binding logics of time, history, and race in order to assemble future machines for transformation. 
Perla 65 


\section{$\underline{\text { Appendix }}$}

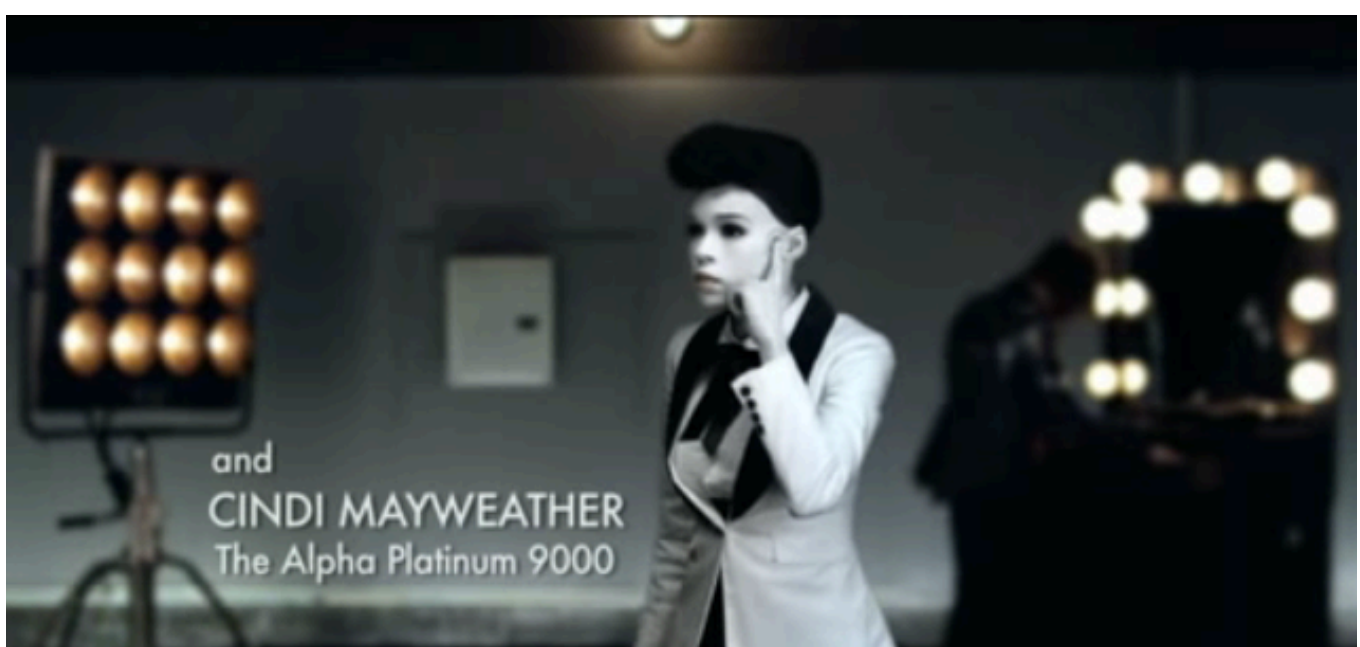

Figure 1: "Android Cindi." Janelle Monáe, 2008.

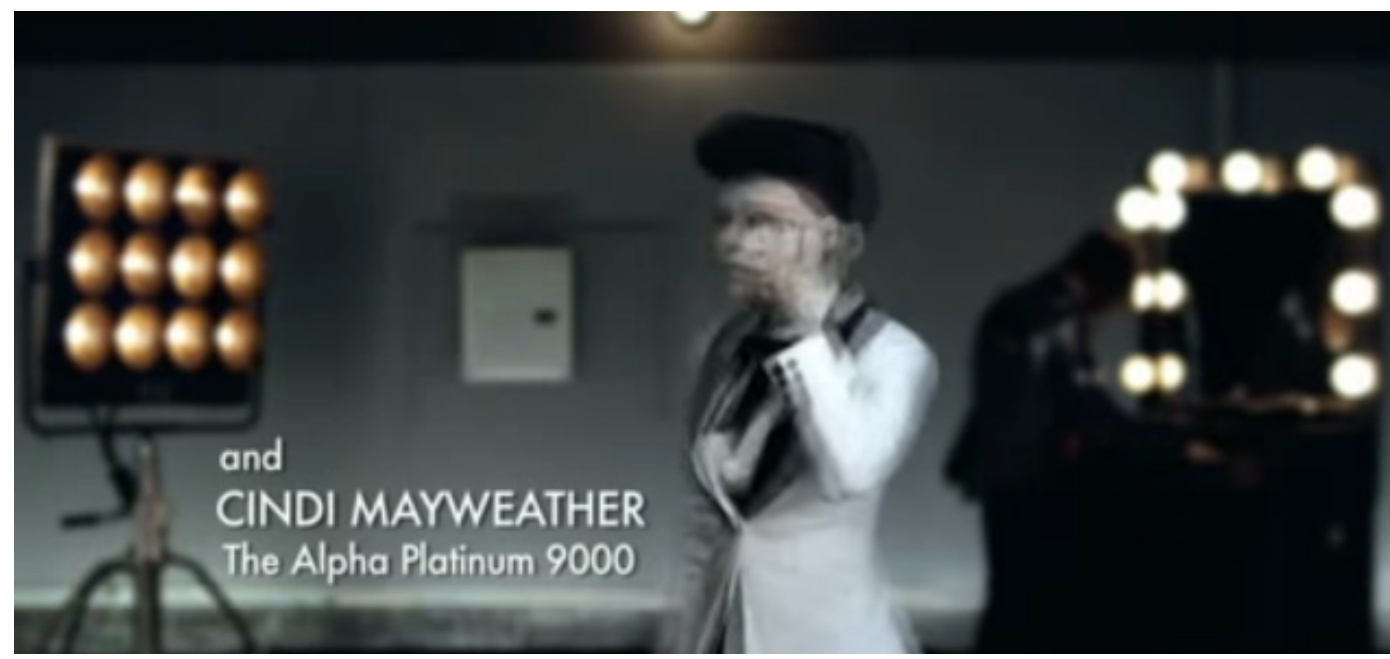

Figure 2: "Cindi Transition." Janelle Monáe, 2008.

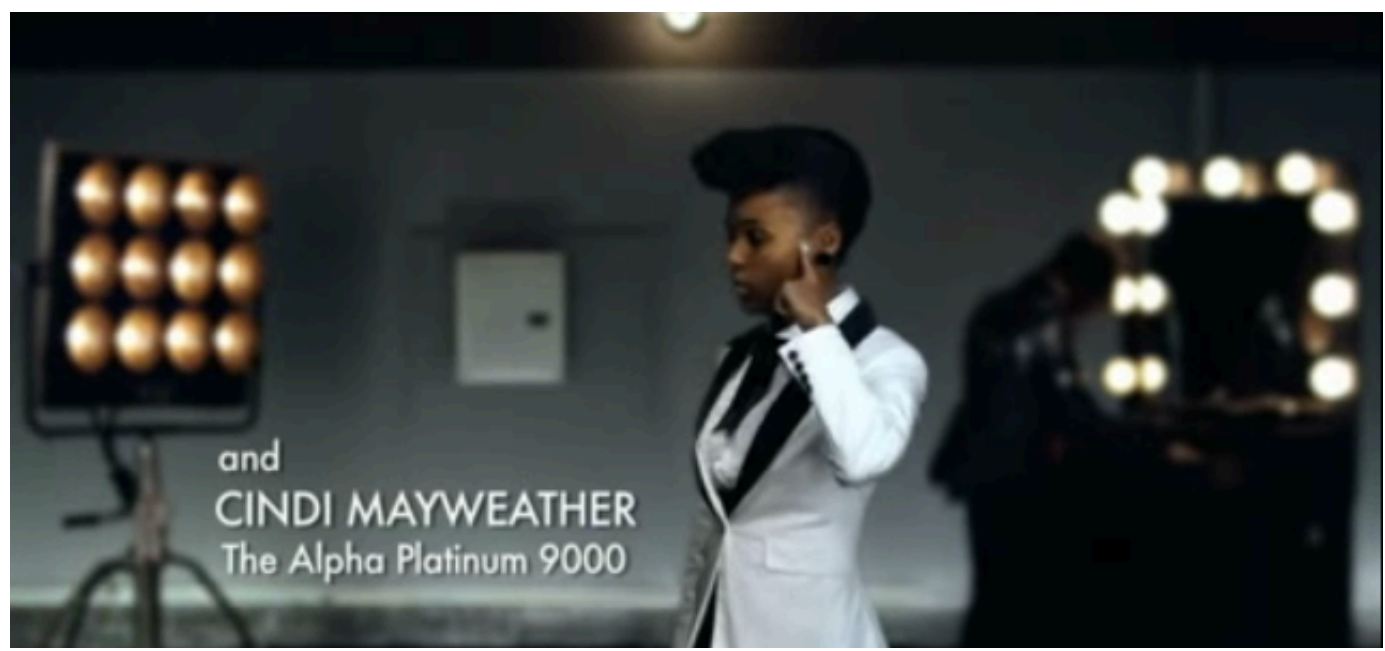

Figure 3: "Cindi Performance Mode." Janelle Monáe, 2008 


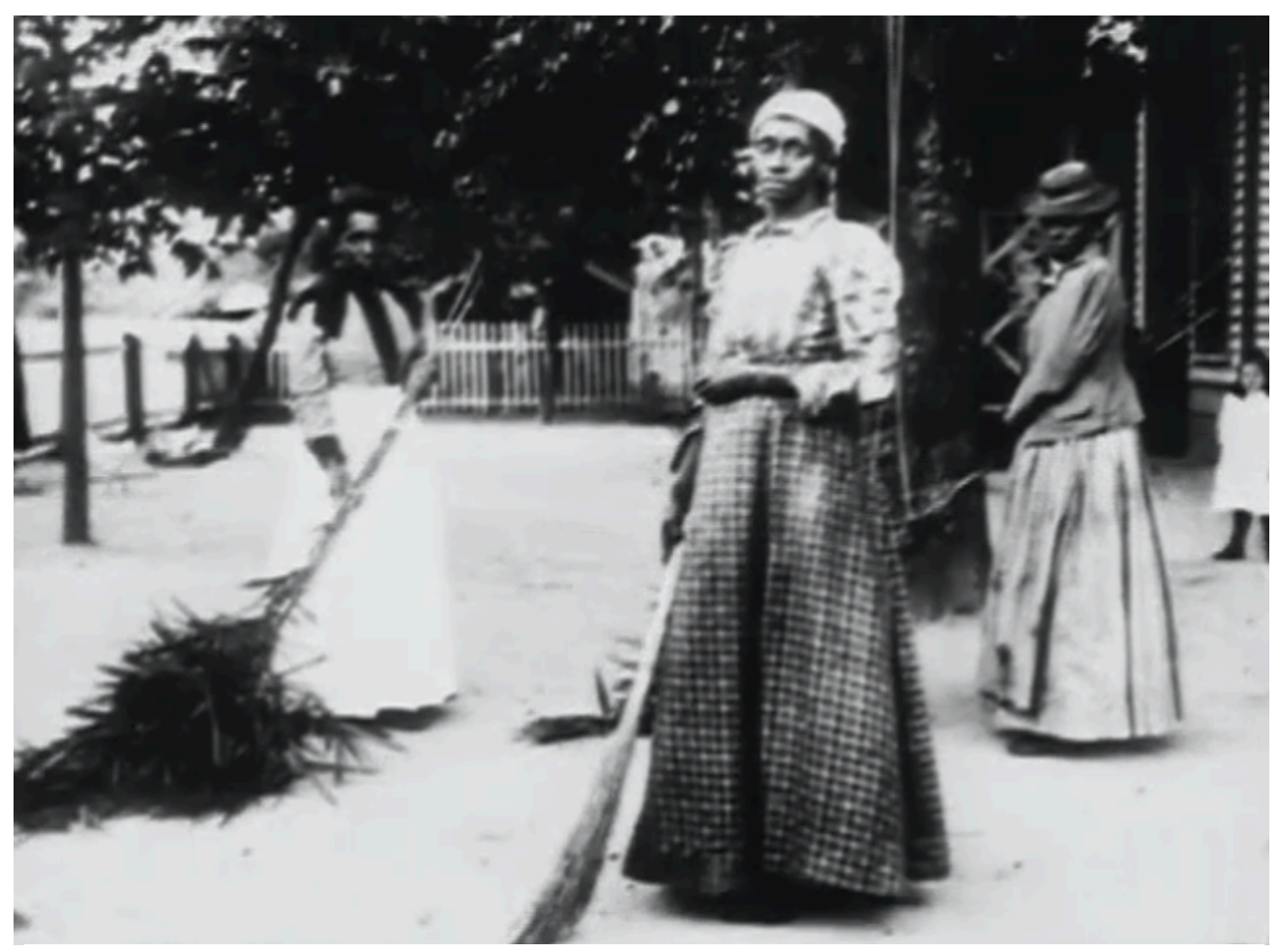

Figure 4: "Women" archival film clip. First Run/Icarus Films, 1995

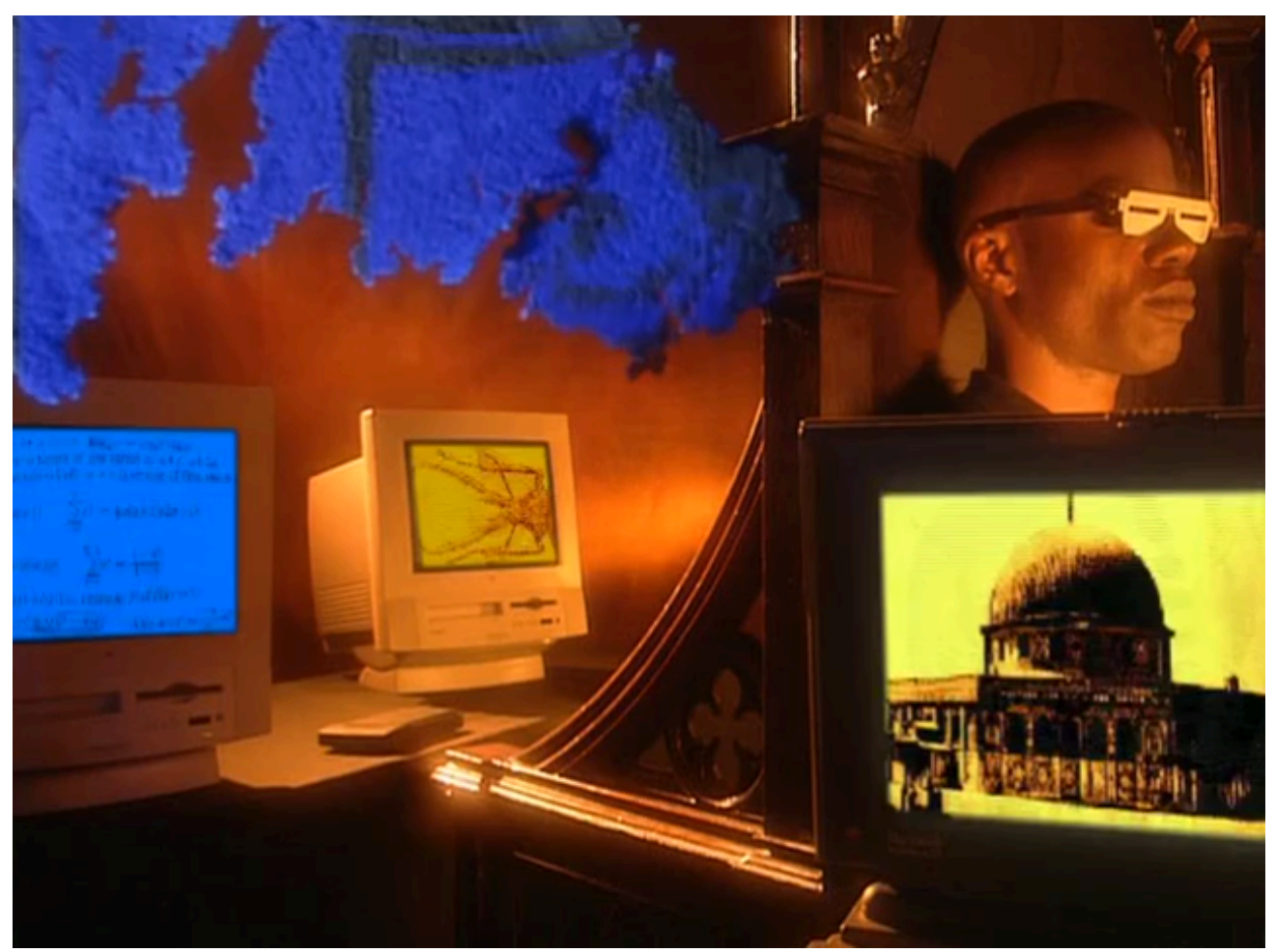

Figure 5: "Data-thief in Internet Room." First Run/Icarus Films, 1995 


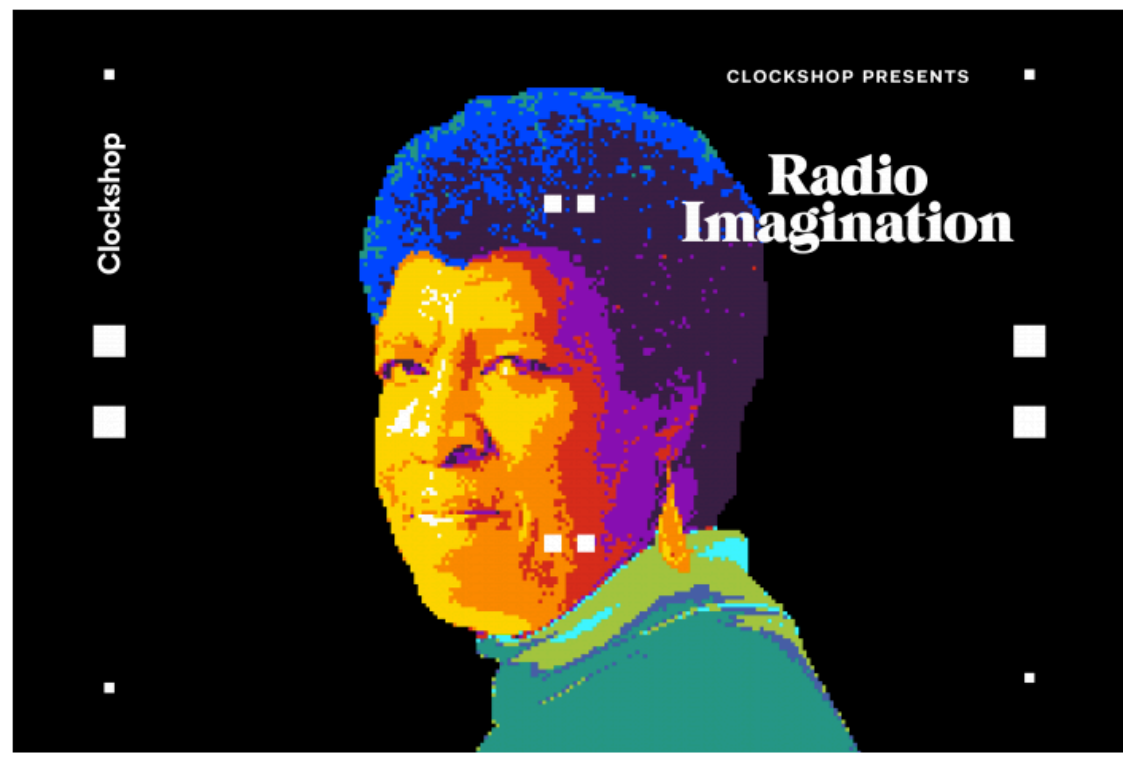

Radio Imagination Launch Party

Figure 6: "Radio Imagination Flyer." Clockshop, 2016

I shall be a bestselling writer.

- f ter I mago, each of my looks will be on the bestseller lists of $\angle A T, N Y T$, PW, WP, etc.. My novels will go onto the alove lists Whether pullishers push them hard or not, Whether I'm paid a high ad vance or not, Whether $d$ ever win another award or not. This is my lite. I write bestselling novels. My novels go onto the best seller lists on or shortly atter pullication. each travel up to the top of and they stay lists and they reach the top and they stay : on top for months 〈at least two . Each of my: novels does this. Sobe it' See to it, sobe it.' See to if! My books will be read by millions of people.

Ill buy a beautitul home in an excellent neigh bornood. I will send poor llack youngsters to Clarion or other writersuths I will help poor flack youngsters broaden thellege

I will help poor thack youngsters gor my mother and myselt I will get the best of health care want or need to. My books will be read by millions of people!

Figure 7: "Butler's Notebook." Octavia E. Butler papers. The Huntington Library, Art Collections, and Botanical Gardens, 1998 
FIGURE 2. THE TIME OF MODERNIZATION

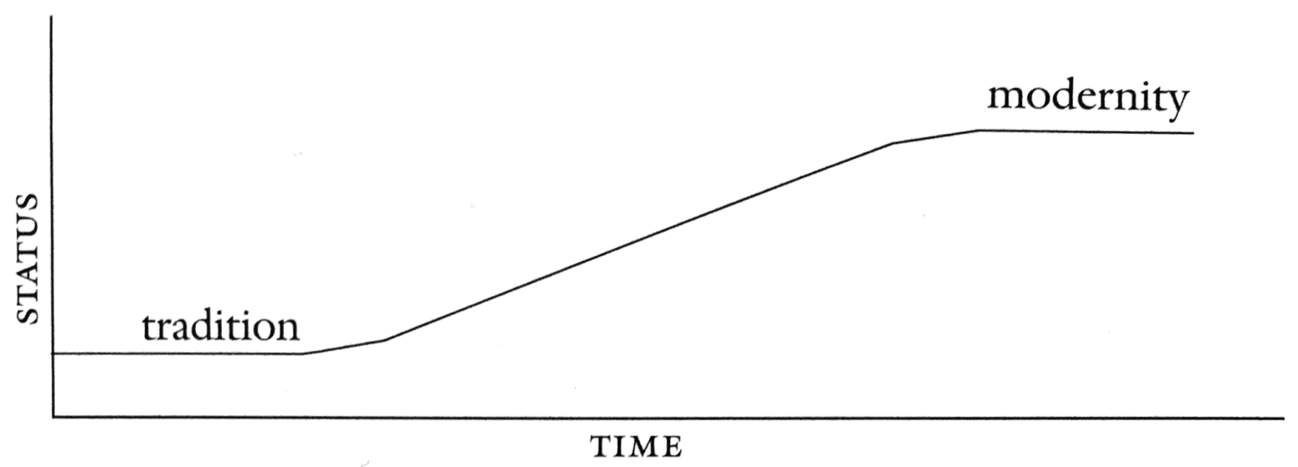

Figure 8: "Time of Modernization." James Ferguson, 2006

FIGURE 3. THE GREAT CHAIN OF BEING

God
rat
frog
worm
animals
Plants
|
Inanimate Matter

Figure 9: "The Great Chain of Being." James Ferguson, 2006 


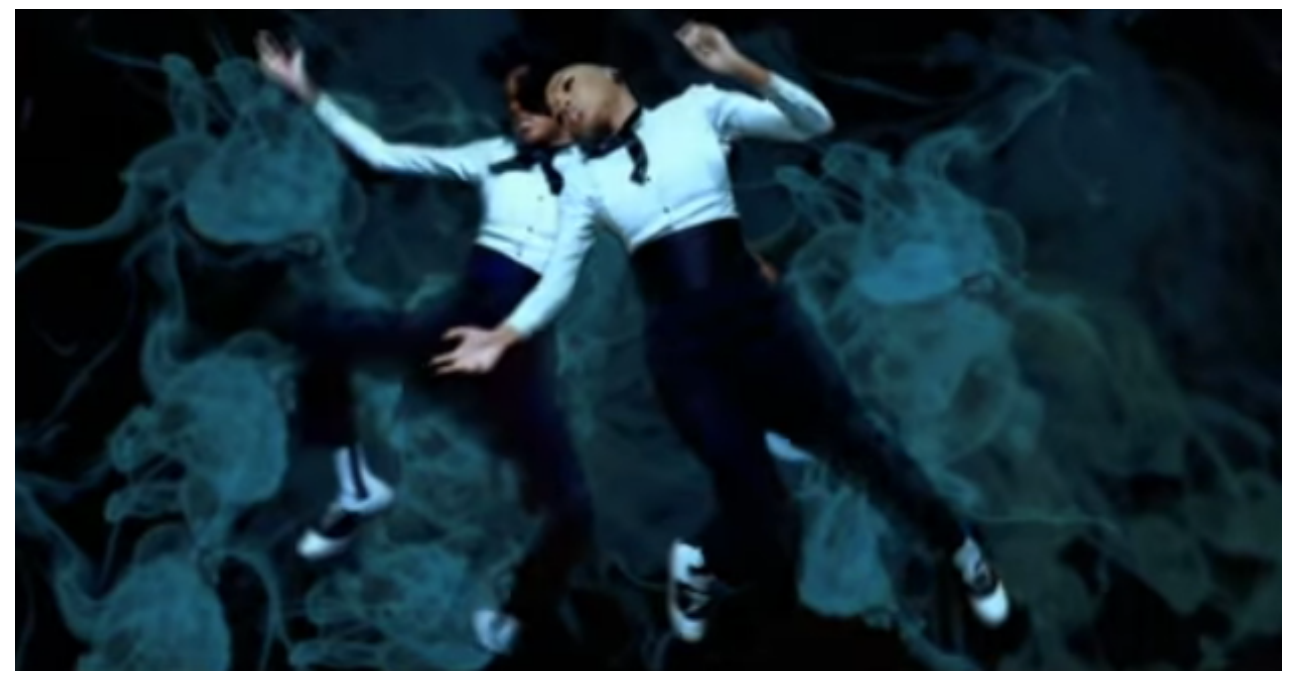

Figure 10: "Disembodiment." Janelle Monáe, 2008.

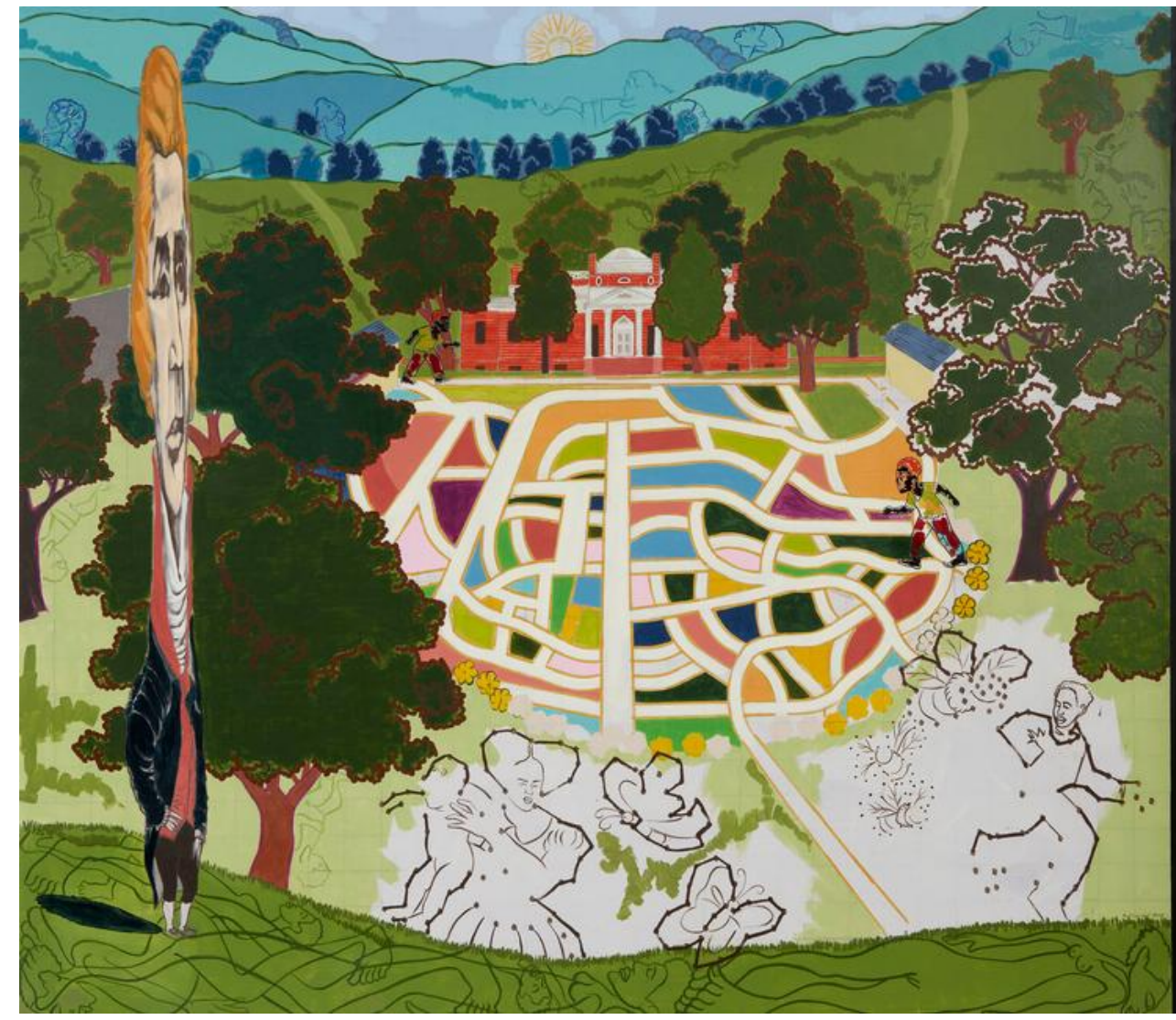

Figure 11: "Visible Means of Support," Kerry James Marshall 2008. Acrillic on PVC Panel 48 x 60 in. Rodney R. Miller Collection, Jack Shainman Gallery, New York 


\section{Perla 71}

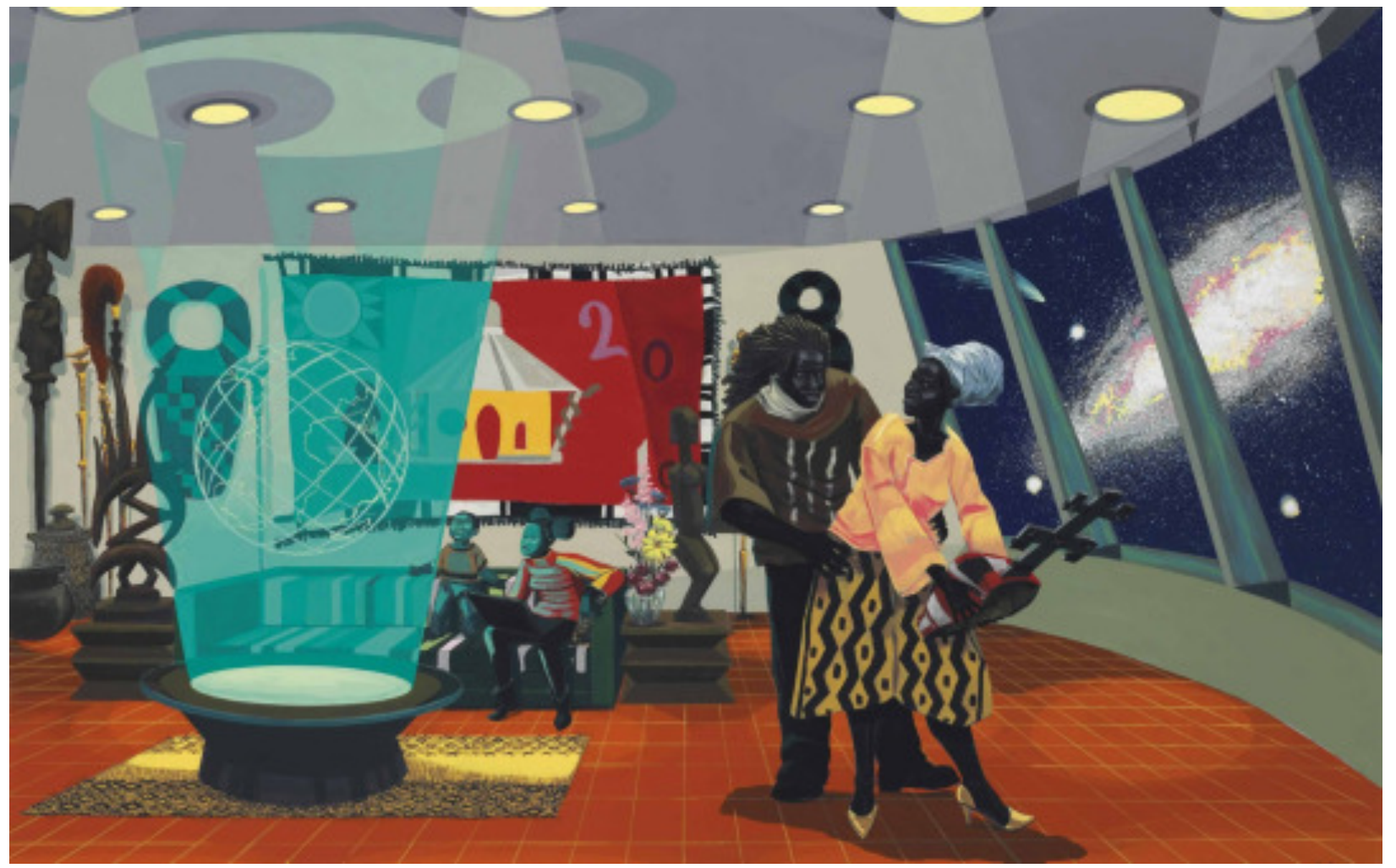

Figure 12: "Keeping the Culture," Kerry James Marshall, 2010. Oil on board 30 x 48 in. Africa House International, Chicago

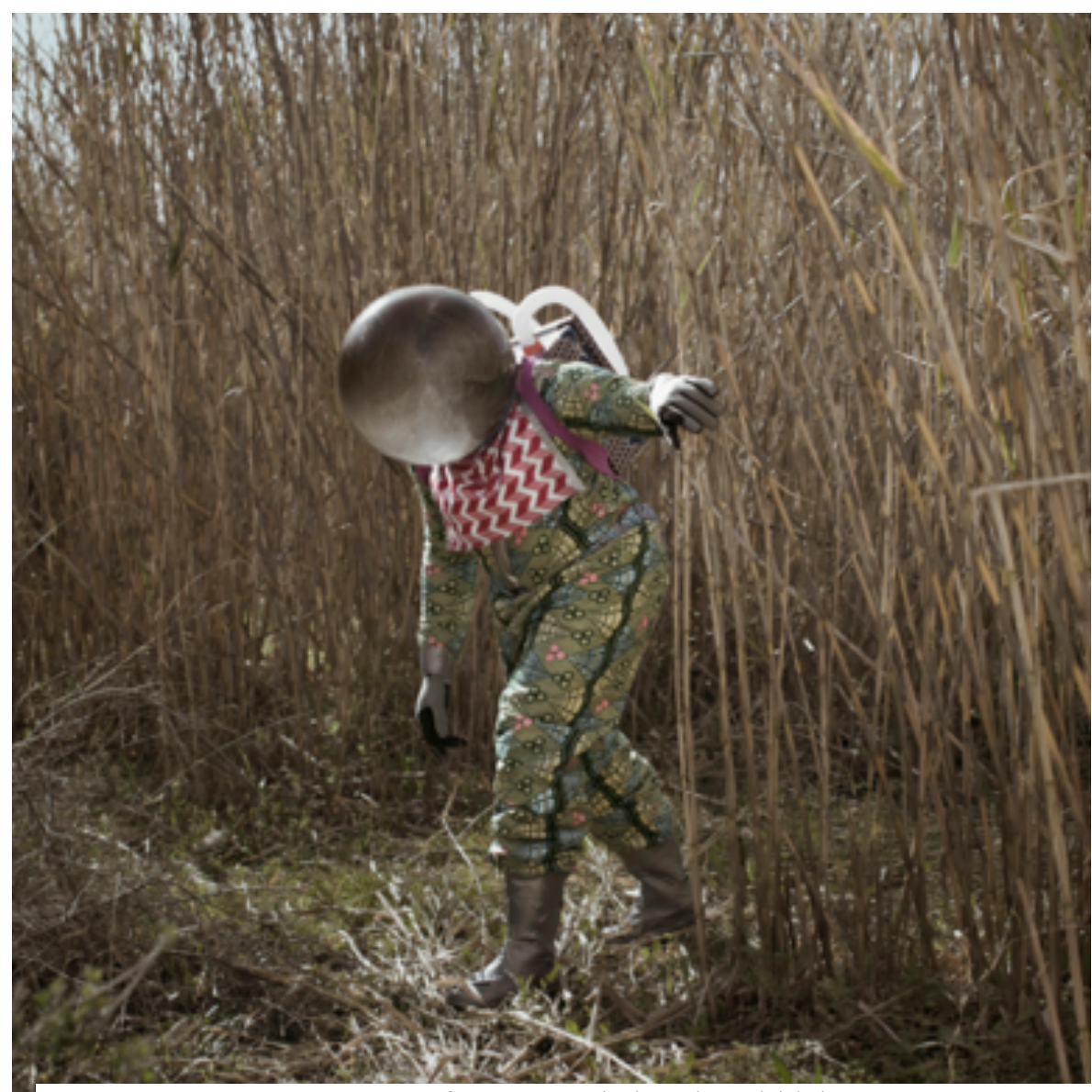

Figure 13: "Afronaut" Cristina de Middel, 2014 


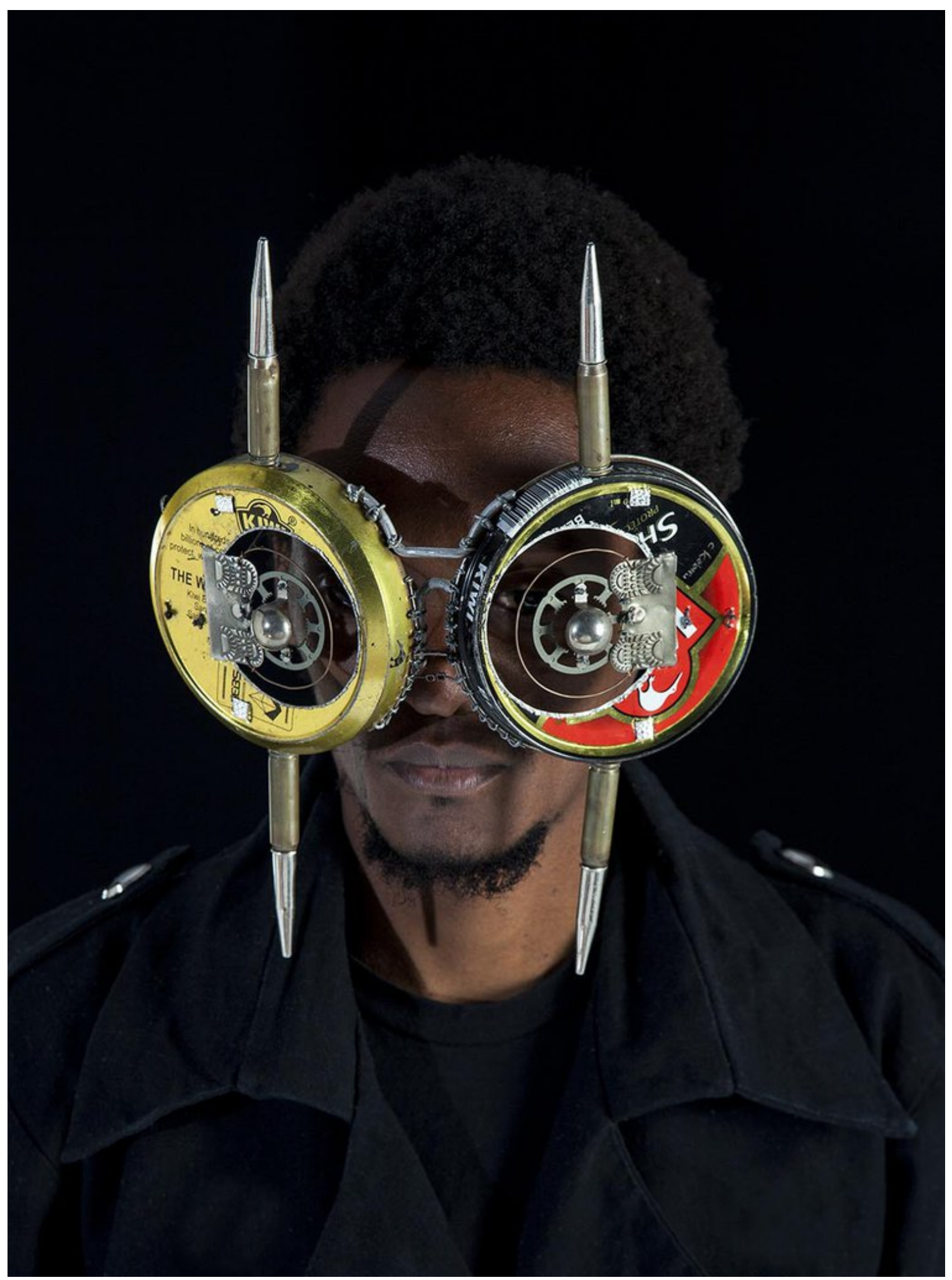

Figure 14: "Westgate 2013." C. Kabriu, 2013 


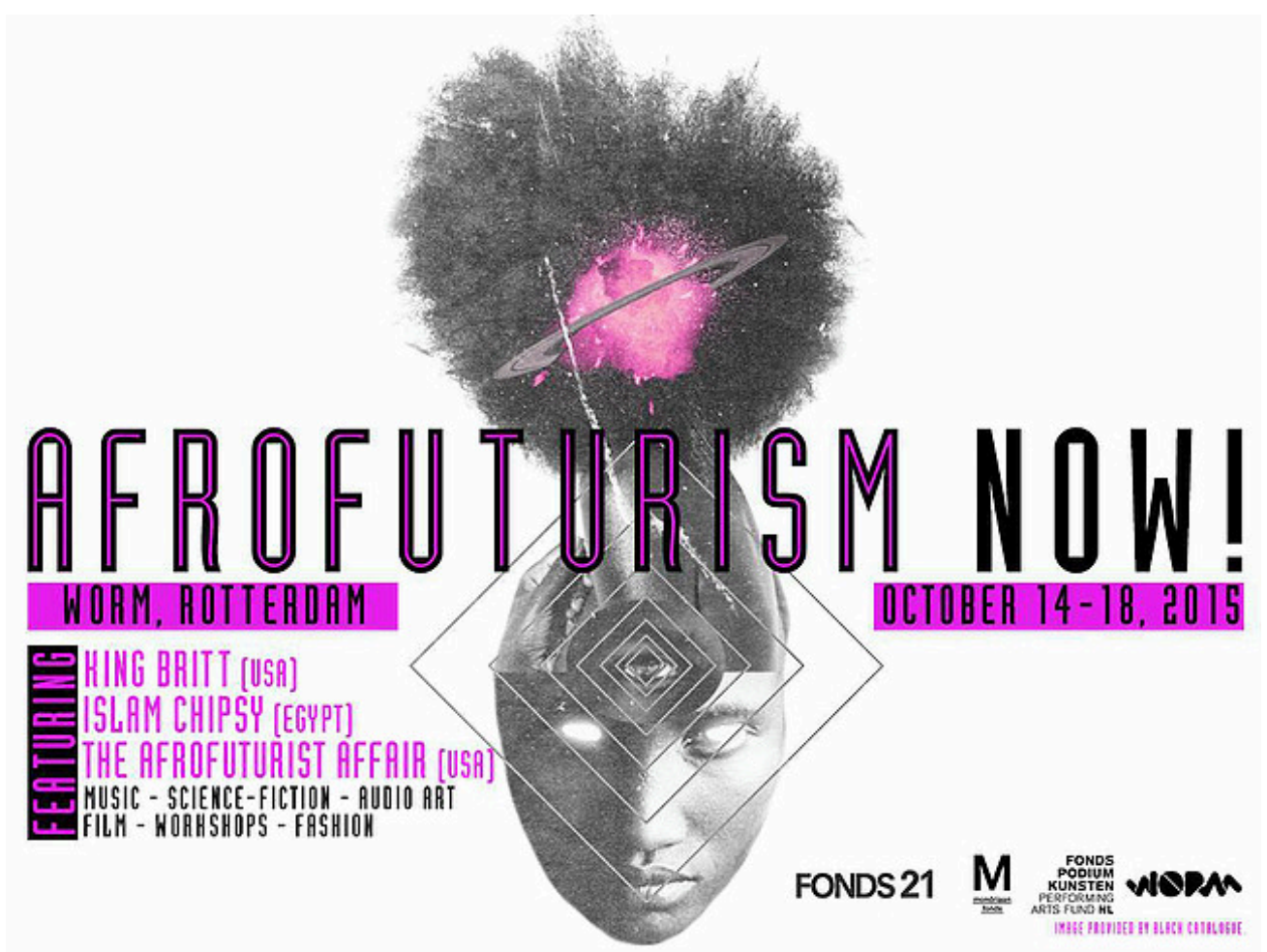

Figure 15: "Afrofuturism Now!" Conference Poster, 2015

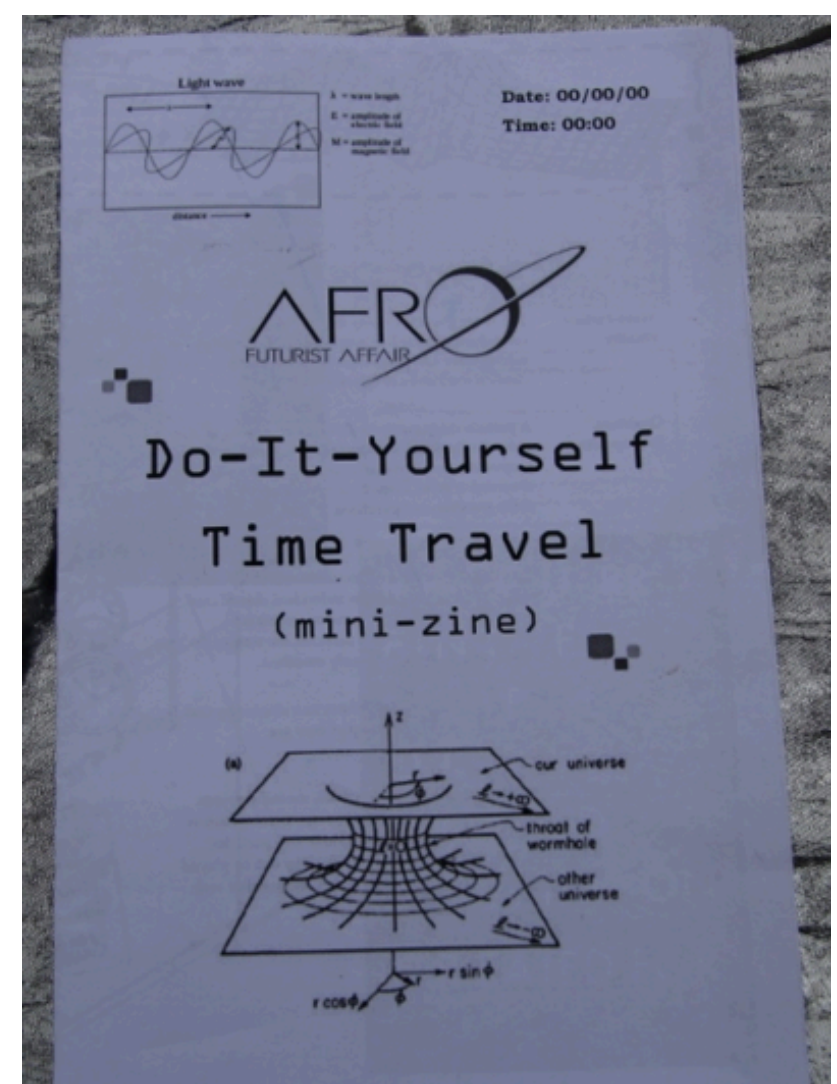

Figure 16: "Screenshot of Do-It-Yourself Time Travel Zine" Afrofuturist Affair, 2014 


\section{Bibliography}

Agusti, Clara Escoda. "The Relationship Between Community and Subjectivity in Octavia E. Butler's Parable of the Sower." Extrapolation 46.3 (2005): 351+

Akomfrah, John, and Black Audio Film Collective. The Last Angel of History. New York: First Run/Icarus Films, 1995.

Baker, Houston A. Blues, Ideology, and Afro-American Literature: a Vernacular Theory. Ed. Chicago: University of Chicago Press, 1987.

Bar, Marleen S. Afro-Future Females: Black Writers Chart Science Fiction's Newest New-wave Trajectory. Columbus: Ohio State University Press, 2008.

Baucom, Ian. Specters of the Atlantic: Finance Capital, Slavery, and the Philosophy of History. Durham: Duke University Press, 2005.

Bogues, Anthony. Empire of Liberty: Power, Desire, and Freedom. Hanover, N.H.: Dartmouth College Press, 2010

Butler, Octavia. Parable of the Sower. A Four Walls Eight Windows 1st ed. New York: Four Walls Eight Windows, 1993.

Butler, Octavia. “'Devil Girl from Mars': Why I Write Science Fiction.” MIT Media in Transition Project. <http://web.mit.edu/comm-forum/papers/butler.html>

Coney, John, Sun Ra, and North American Star System. Space Is the Place. New York: Plexifilm, 1974.

Curtis, Claire P. Postapocalyptic Fiction and the Social Contract: "We'll Not Go Home Again. Lanham, Md.: Lexington Books, 2010.

English, Daylanne K.; Kim, Alvin "Now We Want Our Funk Cut: Janelle Monae's neoAfrofuturism.” American Studies 52.4 (September 22, 2013). 
Ferguson, James. Global Shadows: Africa In the Neoliberal World Order. Durham [ N.C.]: Duke University Press, 2006.

Gilroy, Paul. The Black Atlantic: Modernity and Double Consciousness. Cambridge, Mass.: Harvard University Press, 1993

Glissant, Édouard, trans. Betsy Wing. Poetics of Relation. Ann Arbor: University of Michigan Press, 1997.

Haraway, Donna. Simians, Cyborgs, and Women: The Reinvention of Nature; "Cyborg Manifesto.” Routledge, NY 1991.

Jos, Philip H. "Fear and the Spiritual Realism of Octavia Butler's Earthseed." Utopian Studies 23.2 (October 1, 2012).

Mark 4:1-20. Matthew 13:1-23, Luke 8:1-15. Bible Gateway. Biblica Inc, 2011. Web. $<$ https://www.biblegateway.com/passage/?search=Matthew $+13>$

Marotta, Melanie A. "Liberation Through The Acceptance Of Nature And Technology In Octavia Butler's Parable of the Sower. Theory In Action 3.1 (2010): 38-50.

Mbembe, Achille "African Modes of Self-Writing.." Public Culture 14.1 (2002): 239 273.

Melzer, Patricia "'All That You Touch You Change': Utopian Desire and the Concept of Change in Octavia Butler's Parable of the Sower and Parable of the Talents." FEMSPEC: An Interdisciplinary Feminist Journal Dedicated to Critical and Creative Work in the Realms of Science Fiction, Fantasy, Magical Realism, Surrealism, Myth Folklore, and Other Supernatural Genres 3.2 (January 1, 2002): $31-52$.

Monáe, Janelle. The ArchAndroid. Bad Boy Records, 2010. 
Monáe, Janelle. "Many Moons [Official Short Film]" YouTube video, 6:31. October 3, 2008. https://www.youtube.com/watch?v=LHgbzNHVg0c

Morris, David. "Octavia Butler's (R)evolutionary Movement for the Twenty-First Century." Utopian Studies 26.2 (2015).

Nelson, Alondra. “Afrofuturism: Past-Future Visions.” Colorlines, Spring (2000): 34-37 Nilges, Mathias. "“We Need the Stars": Change, Community, and the Absent Father in Octavia Butler's Parable of the Sower and Parable of the Talents." Callaloo 32.4 (2009).

Phillips, Jerry. "The Intuition Of The Future: Utopia And Catastrophe In Octavia Butler's Parable Of The Sower." Novel: A Forum On Fiction 35.2/3 (2002): 299-311.

Pickens, TA "Octavia Butler and the Aesthetics of the Novel." Hypatia: A Journal of Feminist Philosophy 30.1 (December 1, 2015): 167-180.

Quayson, Ato. Calibrations: Reading for the Social. Minneapolis: University of Minnesota Press, 2003.

Spillers, Hortense; Napier, Winston. "Mama’s Baby, Papa's Maybe.” African American Literary Theory: A Reader. New York: New York University Press, 2000.

Strobel, Nick. "History of Cosmology." University of Oregon, 2015. $<$ http://abyss.uoregon.edu/ js/ast123/lectures/lec01.html $>$

Szwed, John F. Space Is the Place : the Lives and Times of Sun Ra. New York: Pantheon Books, 1997.

Tate, Greg “Diary of a Bug,” Village Voice. Nov. 22, 1988.

Thomas, Sheree R. Dark Matter: a Century of Speculative Fiction From the African Diaspora. New York: Warner Books, 2000. 
Van Veen, Tobias C. "Afrofuturism unbound: Tobias C. van Veen in conversation with Paul D. Miller." Dancecult: Journal of Electronic Dance Music Culture 5.2 (January 1, 2013).

Van Veen, Tobias C. "Vessels of Transfer: Allegories of Afrofuturism in Jeff Mills and Janelle Monáe." Dancecult: Journal of Electronic Dance Music Culture 5.2 (January 1, 2013).

Ward, Paul. "Black Audio Film Collective (1982-98).” Reference Guide to British and Irish Film Directors. ScreenOnline, 2013 $<$ http://www.screenonline.org.uk/people/id/502424/>

Womack, Ytasha. Afrofuturism: the World of Black Sci-fi and Fantasy Culture. First edition Chicago: Chicago Review Press, 2013. 